\title{
An End-to-End Model Reveals Losers and Winners in a Warming Mediterranean Sea
}

\author{
Fabien Moullec ${ }^{1 *}$, Nicolas Barrier², Sabrine Drira1 , François Guilhaumon ${ }^{1,3}$, \\ Patrick Marsaleix ${ }^{4}$, Samuel Somot ${ }^{5}$, Caroline Ulses ${ }^{4}$, Laure Velez ${ }^{1}$ and Yunne-Jai Shin ${ }^{1,6}$ \\ ${ }^{1}$ MARBEC, CNRS, Ifremer, IRD, Université de Montpellier, Montpellier, France, ${ }^{2}$ MARBEC, CNRS, Ifremer, IRD, Université \\ de Montpellier, Sète, France, ${ }^{3}$ Laboratoire d'Excellence CORAIL, ENTROPIE, IRD, CNRS, Université de La Réunion, \\ Saint-Denis, France, ${ }^{4}$ Laboratoire d'Aérologie, CNRS, UPS, Université de Toulouse, Toulouse, France, ${ }^{5}$ CNRM, CNRS, \\ Météo-France, Université de Toulouse, Toulouse, France, ${ }^{6}$ Department of Biological Sciences, Marine Research Institute, \\ University of Cape Town, Rondebosch, South Africa
}

\section{OPEN ACCESS}

Edited by: Elizabeth Fulton, Commonwealth Scientific and Industrial Research Organisation (CSIRO), Australia

Reviewed by:

Cameron Ainsworth, University of South Florida,

United States

Nova Mieszkowska, University of Liverpool, United Kingdom

*Correspondence:

Fabien Moullec

fabien.moullec@ird.fr

Specialty section:

This article was submitted to Global Change and the Future Ocean,

a section of the journal Frontiers in Marine Science

Received: 31 March 2019 Accepted: 05 June 2019

Published: 25 June 2019

Citation:

Moullec F, Barrier N, Drira S, Guilhaumon F, Marsaleix P, Somot $S$, Ulses C, Velez L and Shin Y-J (2019) An End-to-End Model Reveals Losers and Winners in a Warming Mediterranean Sea.

Front. Mar. Sci. 6:345. doi: 10.3389/fmars.2019.00345
The Mediterranean Sea is now recognized as a hotspot of global change, ranking among the fastest warming ocean regions. In order to project future plausible scenarios of marine biodiversity at the scale of the whole Mediterranean basin, the current challenge is to develop an explicit representation of the multispecies spatial dynamics under the combined influence of fishing pressure and climate change. Notwithstanding the advanced state-of-the-art modeling of food webs in the region, no previous studies have projected the consequences of climate change on marine ecosystems in an integrated way, considering changes in ocean dynamics, in phyto- and zoo-plankton productions, shifts in Mediterranean species distributions and their trophic interactions at the whole basin scale. We used an integrated modeling chain including a high-resolution regional climate model, a regional biogeochemistry model and a food web model OSMOSE to project the potential effects of climate change on biomass and catches for a wide array of species in the Mediterranean Sea. We showed that projected climate change would have large consequences for marine biodiversity by the end of the 21 st century under a business-as-usual scenario (RCP8.5 with current fishing mortality). The total biomass of high trophic level species (fish and macroinvertebrates) is projected to increase by 5 and $22 \%$ while total catch is projected to increase by 0.3 and $7 \%$ by $2021-2050$ and 2071-2100, respectively. However, these global increases masked strong spatial and inter-species contrasts. The bulk of increase in catch and biomass would be located in the southeastern part of the basin while total catch could decrease by up to $23 \%$ in the western part. Winner species would mainly belong to the pelagic group, are thermophilic and/or exotic, of smaller size and of low trophic level while loser species are generally large-sized, some of them of great commercial interest, and could suffer from a spatial mismatch with potential prey subsequent to a contraction or shift of their geographic range. Given the already poor conditions of exploited resources, our results suggest the need for fisheries management to adapt to future changes and to incorporate climate change impacts in future management strategy evaluation.

Keywords: biodiversity scenario, climate change, ecosystem model, end-to-end model, OSMOSE, fishing, Mediterranean Sea 


\section{INTRODUCTION}

Climate change and ocean acidification are altering oceans at rates that have been unprecedented over the last millennia (IPCC, 2014; Howes et al., 2015; Weatherdon et al., 2016). Such changes in ocean conditions have numerous impacts scaling from individuals up to ecosystems, jeopardizing ecosystem goods and services as well as human societies (Brown et al., 2010; Ainsworth et al., 2011; Cheung et al., 2013; Pecl et al., 2017). Following environmental changes, the physiology of marine organisms, population dynamics, ecological interactions, and entire marine food webs are or will be, directly or indirectly, impacted (Parmesan and Yohe, 2003; Cheung et al., 2013; Albouy et al., 2014; Poloczanska et al., 2016; Henson et al., 2017; Miller et al., 2018; Selden et al., 2018). Climate change will affect all ocean organisms and primary productivity, change the composition of marine communities, and alter ecosystem functions such as the production of marine living resources (Brown et al., 2010; Hoegh-Guldberg and Bruno, 2010; Blanchard et al., 2012; Holt et al., 2016).

With growing human populations, rising incomes, and changing dietary preferences, the global demand for fish is expected to increase in the future while climate-induced changes are expected to change future fisheries production patterns dramatically, either by shifting spatial patterns of production as species tend to track their suitable environmental niche or as a result of changes in net primary production (Perry et al., 2005; Brander, 2007; Cheung et al., 2010; Merino et al., 2012; Barange et al., 2014; IPCC, 2014; Cheung, 2018; FAO, 2018). For example, the spatial distribution of fish has been shown to shift toward higher latitude regions or into deeper waters, with rates of range shift of ca. $30-130 \mathrm{~km}$ decade $^{-1}$ toward the poles and $3.5 \mathrm{~m} \mathrm{decade}^{-1}$ to deeper waters (Cheung et al., 2010; Cheung, 2018). Regarding global primary production, 10 earth system models projected a mean global decrease of $8.6 \%( \pm 7.9 \%)$ under the highest emission scenario RCP8.5 (Representative Concentration Pathway) and a decrease of $2 \%( \pm 4.1 \%)$ under the high mitigation scenario RCP 2.6 by 2090, with large regional differences (Bopp et al., 2013). These changes are likely to trigger a global redistribution of the maximum catch potential (MCP) of fishing areas, with MCP and global revenue projected to decrease by 7.7 and $10.4 \%$, respectively, by 2050 relative to 2000 when considering RCP8.5 (Lam et al., 2016). Using a dynamic size-based food web model forced by a physical-biogeochemical model, Blanchard et al. (2012) predicted a decline of $30-60 \%$ in potential fish production in some tropical and upwelling areas and an increase in the production of pelagic predators by $28-89 \%$ in some high latitude shelf seas by 2050 under the SRES A1B scenario (Special Report on Emissions Scenarios). According to Carozza et al. (2018), climate change could decrease the global fish biomass by as much as $30 \%$ by 2100 (RCP8.5), because of changes in primary production and a temperature-driven increase of natural mortality. From an ensemble of ecosystem models included in the Fisheries and Marine Ecosystem Model Inter-comparison Project (Fish-MIP), a 15-30\% decline of the total marine animal biomass in the North and South Atlantic, Pacific, and Indian Ocean is projected by 2100 , whereas polar ocean basins would experience a $20-80 \%$ increase under a high emission scenario (RCP8.5) (Bryndum-Buchholz et al., 2019). It turns out that climate change can significantly alter the availability and composition of commercial fisheries catches, thereby having socioeconomic implications for fisheries, markets, and consumers worldwide (Weatherdon et al., 2016).

The Mediterranean Sea, bordered by Africa, Europe, and Asia (Figure 1), is one of the most responsive regions to climate change (Giorgi, 2006; Marbà et al., 2015), with various sources of disturbance interacting synergistically (Coll et al., 2012; Micheli et al., 2013; Ramírez et al., 2018). Several studies conducted in the region have already explored the impacts of climate change on marine populations, species assemblages and ecosystem structures (Ben Rais Lasram and Mouillot, 2008; Ben Rais Lasram et al., 2010; Lejeusne et al., 2010; Albouy et al., 2012, 2013, 2014; Coll et al., 2012; Tsikliras and Stergiou, 2014; Halpern et al., 2015; Marbà et al., 2015; Hattab et al., 2016). Under a high emission scenario (SRES A2 scenario), Albouy et al. (2013) showed that by the end of the century, 54 out of 288 coastal fish species are expected to lose their climatically suitable habitat, species richness would decrease across $70.4 \%$ of the continental shelf area and mean fish body size would increase over $74.8 \%$ of the continental shelf area. Under the same climate change scenario, Ben Rais Lasram et al. (2010) suggested that the coldest areas of the Mediterranean Sea (i.e., the Adriatic Sea and the Gulf of Lions) would first act as refuges for cold-water species then would become a "cul-de-sac" driving those species toward extinction by the end of the century.

Most of the future projections conducted so far at the Mediterranean basin scale have been based on climate niche models, and none have projected future changes in trophic and ecosystem functioning as well as in biomass evolution or fisheries catch at the whole basin scale under climate change. Several local scale scenarios of climate change impacts involved the Ecopath with Ecosim modeling approach (Coll and Libralato, 2012; Libralato et al., 2015; Corrales et al., 2018), focused on trophic fluxes within food webs, with most of the dynamics being non-spatially explicit (Brander, 2010; Perry et al., 2010; Urban et al., 2016). A few global scale models provided some quantification of the climate-induced changes to be expected for the Mediterranean Sea, but these were typically developed using physical and biogeochemical models at a spatial resolution probably too low to properly reflect the very complex Mediterranean dynamics (e.g., Cheung et al., 2010, 2016, 2018). Yet, not all these studies have studied the consequences of climate change on Mediterranean marine ecosystems in an integrated way: considering changes in ocean dynamics, in plankton production, shifts in species distributions, their life cycles and their trophodynamic interactions. Consideration of these processes is critical to fully address the future of marine biodiversity, and to explore robust mitigation and adaptation strategies in response to global changes. Representing the strength of food web connections and developing holistic approaches are fundamental to project the response of ecosystems under bottom-up and top-down forcing, such as climate-driven changes or over-exploitation of living marine resources (Perry et al., 2010; Grimm et al., 2017; 


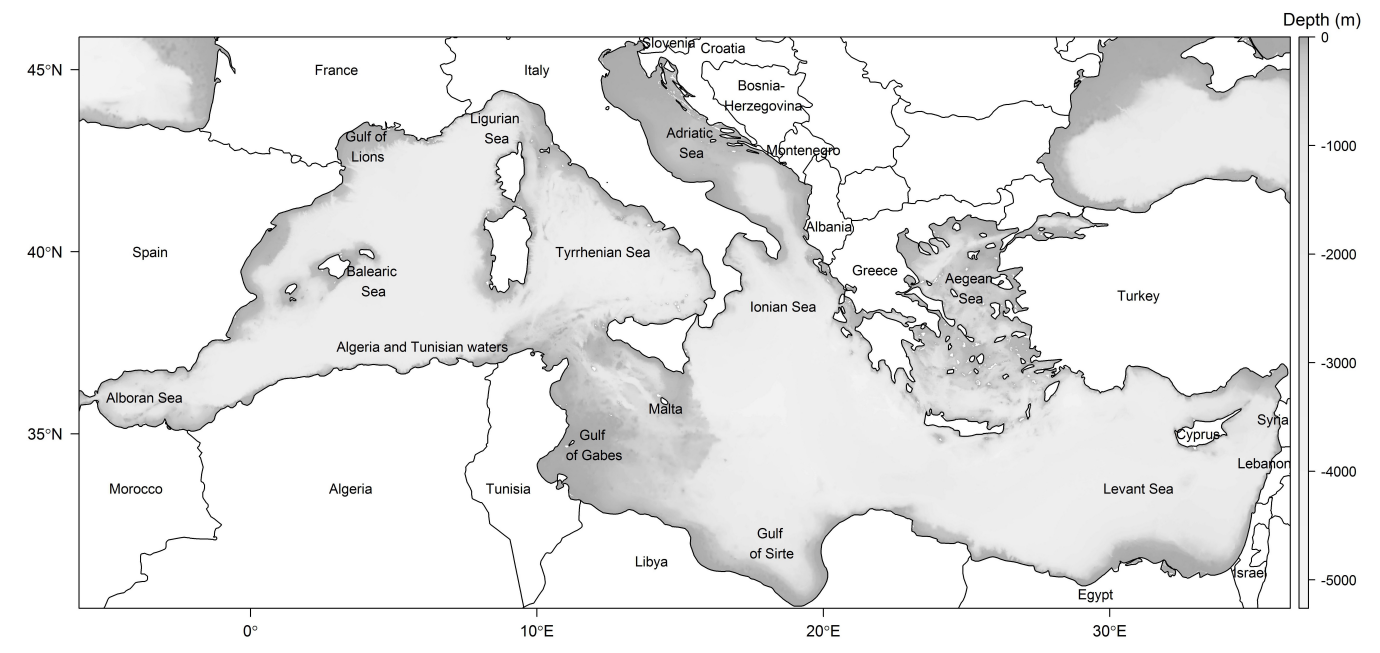

FIGURE 1 | Main biogeographic regions, basins, and maximum average depth $(\mathrm{m})$ in the Mediterranean Sea.

Seidl, 2017; Cheung, 2018; Nicholson et al., 2018; Peck et al., 2018; Selden et al., 2018). Such scientific progress is needed to support an ecosystem-based approach to marine resources management (EAM) (Garcia et al., 2003; Pikitch et al., 2004; Coll and Libralato, 2012; Coll et al., 2013) and to advance the sustainable use and conservation of the oceans (UN Sustainable Development goal 14; Pecl et al., 2017).

In this context, we used an integrated modeling chain including a high-resolution regional climate model, a regional biogeochemistry model and a food web model (Moullec et al., 2019) to project the potential effects of climate change on biomass and catches for a wide array of species in the Mediterranean Sea, by the middle and end of the 21st century under the high-emission RCP8.5 socio-economic scenario and "business as usual" fisheries management (i.e., current fishing mortality). With this modeling chain, primary and secondary production changes and spatial distribution shift of species induced by climate change were considered. We aimed to explore how climate-induced changes could affect the Mediterranean marine biodiversity, as well as the ecosystem structure and functioning, by using a set of ecological indicators relevant at different scales, from individuals to communities and from ecoregions to the whole Mediterranean Sea.

\section{MATERIALS AND METHODS}

\section{General Structure of the End-to-End Modeling Chain}

In this study, we used a consistent end-to-end modeling chain from global climate to regional marine ecosystem under the RCP8.5 scenario. The RCP8.5 scenario from the IPCC AR5 is characterized by increasing greenhouse gas emissions (GHG) over time, leading to high GHG concentration levels in 2100 (Riahi et al., 2011). It assumes a high population growth rate and relatively slow income growth with modest rates of technological change and energy intensity improvements (Riahi et al., 2011). In terms of expected global temperature increase by the end of the century, the RCP8.5 scenario can be considered close to the IPCC SRES A1F1 and A2 scenario (Rogelj et al., 2012). It was chosen here as the range of projected temperatures were the most frequently explored in the region (Albouy et al., 2014; Hattab et al., 2016; Benedetti et al., 2018; Corrales et al., 2018), hence facilitating comparisons with previous findings.

Our modeling chain includes:

(1) A general circulation model (GCM), CNRM-CM5 (Voldoire et al., 2013), that simulates the past and future evolution of the various components (atmosphere, ocean, land surface, river, cryosphere) of the global climate system.

(2) A regional climate model, CNRM-RCSM4 (Sevault et al., 2014), that simulates at high spatial resolution various components (atmosphere, ocean, land surface, river) of the Mediterranean regional climate system.

(3) A regional biogeochemistry model, Eco3M-S (Auger et al., 2011) that simulates at high-resolution the biogeochemistry cycles and the lower trophic level species (i.e., plankton) of the Mediterranean Sea.

(4) A multispecies dynamic model (OSMOSE ${ }^{1}$; Moullec et al., 2019), that represents at high-resolution the spatial dynamics of interacting high trophic level species in the Mediterranean Sea.

In this chain, CNRM-RCSM4 is driven one-way by atmosphere and ocean lateral boundary conditions extracted from CNRM-CM5 (see Supplementary Material S1 for details). Eco3M-S is itself driven one-way by the atmosphere and ocean outputs of CNRM-RCSM4. Finally, OSMOSE is driven one-way by the biogeochemistry outputs of Eco3M-S (i.e., by phyto- and zoo-plankton biomass). This end-to-end

\footnotetext{
${ }^{1}$ http://www.osmose-model.org
} 
model is fully described in Moullec et al. (2019), only a brief presentation of the structure and parameterization is given in the present study. Details on the OSMOSE model can be found at https://documentation.osmose-model.org/index.html.

Despite the complexity of the modeling chain, we consider that it represents the best solution to date to combine in a consistent way and at high-resolution all the drivers required to assess the future evolution of the Mediterranean upper trophic species. We acknowledge, however, that we are exploring here only one possible modeling chain among a large ensemble of possibility and in particular, we do not explore the uncertainty related to the choice of each modeling block.

\section{The Regional Biogeochemistry Model Eco3M-S}

Eco3M-S is a biogeochemical model which simulates the lower trophic part of the food web. It represents several elements' cycles such as carbon, nitrogen, phosphorus and silica in order to reproduce the different limitations and co-limitations observed in the Mediterranean Sea and the dynamics of different plankton groups (Auger et al., 2011). Seven planktonic functional types (PFTs), characterized by a specific size range and representing the main PFTs of the Mediterranean Sea were modeled: Pico(0.7-2 $\mu \mathrm{m}$, mainly Synechococcus spp.), nano- (2-20 $\mu \mathrm{m}$, mainly dinoflagellates), and micro-phytoplankton (20-200 $\mu \mathrm{m}$, mainly diatoms); nano- (5-20 $\mu \mathrm{m}$, mainly bacterivorous flagellates and small ciliates), micro- (20-200 $\mu \mathrm{m}$, mainly ciliates and large flagellates), and meso- zooplankton (>200 $\mu \mathrm{m}$, mainly copepods and amphipods) and heterotrophic bacteria (not considered in the present study). All features, formulations, and parameterization of biogeochemical processes integrated in the mechanistic Eco3M-S model were described in details by Auger et al. (2011) and Ulses et al. (2016).

The coupling between Eco3M-S and OSMOSE was realized through (i) the spatial distribution of high trophic level species (HTL) in OSMOSE and (ii) the predation process with the planktonic organisms from Eco3M-S serving as potential prey fields (in the form of biomass) for the HTL species in OSMOSE. As within OSMOSE, predation upon planktonic groups is an opportunistic size-based process (Travers-Trolet et al., 2014a) controlled by a minimum and a maximum predation size ratio parameter.

\section{The High Trophic Level Model OSMOSE}

OSMOSE is a multispecies and individual-based model, spatially explicit and representing the whole life cycle of several interacting marine species from eggs to adult stages. Major processes of the life cycle, i.e., growth, predation, reproduction, natural, and starvation mortalities as well as fishing mortality, are modeled with a time step of 2-weeks in this study. Species interact through predation in a spatial and dynamic way (Shin and Cury, 2001, 2004). The predation process occurs when there are both spatio-temporal co-occurrence and size compatibility between a predator and its prey. The model is forced by species-specific spatial distribution maps (one unique map per species in this study) (see section "Current and Future Species Geographic
Distributions"). A maximum and a minimum predator/prey size ratio are defined to constrain predator prey interactions. The food web structure thus emerges from these local individual interactions (Travers et al., 2009; Travers-Trolet et al., 2014b).

OSMOSE covers the whole Mediterranean basin with a regular grid of $20 \mathrm{~km} \times 20 \mathrm{~km}$ counting 6229 cells. It represents the Mediterranean food web from plankton production to main apex predators on the 2006-2013 period (Moullec et al., 2019). Ninetyseven high trophic level species (82 fish species, 5 cephalopod species, and 10 crustacean species, mainly shrimps) were modeled, accounting for around $95 \%$ of total declared catches in the region during the 2006-2013 period. Modeled species were selected according to their ecological and economic importance and Data Availability (Moullec et al., 2019). For this study, three amphihaline fish species (i.e., Alosa alosa, Alosa fallax, and Anguilla anguilla) were removed from the previous version of the model because their complex life cycle characterized by movements between fresh-water and salt-water has not been modeled as being influenced by climate change. A benthos compartment was added and modeled with just a few parameters (i.e., size range, trophic level, and biomass) to take into account the diet specificity of some HTL species that partly feed on benthic invertebrates (e.g., crustaceans, polychaetes) (Moullec et al., 2019). The biological parameters linked to somatic growth (Von Bertalanffy parameters, length-weight relationship parameters), mortalities (longevity, additional natural mortality that is not explicitly represented in OSMOSE, age/size at fisheries recruitment), reproduction (size at maturity, relative fecundity) and predation (minimum and maximum predation size ratios, maximum ingestion rate), along with their sources, are detailed in the Supplementary Tables S1, S2.

\section{Implementation of the Future Scenario Current and Future Species Geographic Distributions}

A niche modeling approach based on environmental data was used to generate species presence/absence maps in the Mediterranean Sea and drive species spatial distributions in OSMOSE (Moullec et al., 2019). Environmental predictor variables, i.e., temperature, salinity, were extracted from the World Ocean Atlas 2013 version $2^{2}$ which provides observed climate data over the 1975-2012 period. To take into account the vertical distribution of species in the water column, six environmental metrics were derived from monthly temperature and salinity climatologies: mean sea surface temperature and salinity (0-50 $\mathrm{m}$ depth), mean vertical temperature and salinity (0-200 m depth), and mean sea bottom temperature and salinity (50 $\mathrm{m}$ - maximum bathymetry depth).

Current geographic distributions were modeled using an ensemble forecasting approach involving eight climate suitability models embedded in the freeware BIOMOD2 R package (Thuiller et al., 2009; R Core team, 2015) (see Moullec et al., 2019 for details on models parameterization and assumptions). The niche models developed and calibrated under present conditions were then used to project the environmental niche of species to the 2021-2050 and 2071-2100 periods using future environmental

\footnotetext{
${ }^{2}$ https://www.nodc.noaa.gov/OC5/woa13/woa13data.html
} 
predictors. A threshold approach maximizing the fit with current species distribution was used to predict the geographical range of the species under both current and future environmental conditions. In this study, only the current and future geographic distributions of species already present in the Mediterranean Sea before the year 2013 and for which the biological knowledge necessary for the parameterization of the OSMOSE model is available were modeled. We included potential invasive species, which distribution centroid and main abundance are located outside the Mediterranean Sea, but which have been observed in Mediterranean waters, even in small numbers. No new introduction of non-indigenous marine species has been considered.

Sea temperature and salinity values at different depth strata were obtained for the historical period (1970-2005), the middle (2021-2050), and the end of the 21st century (2071-2100) from CNRM-RCSM4. For projecting the future species geographical distribution, a deltas method was used: anomalies between the historical simulated period (1970-2005) and the future projected periods were calculated and applied to current climate temperature and salinity climatologies to create future environmental conditions.

\section{Future Plankton Productions}

The same deltas approach was followed for the biogeochemistry forcing extracted from Eco3M-S: anomalies between the historical and future time periods (2021-2050 and 2071-2100) were calculated and applied to current plankton biomasses.

Transient biogeochemical simulations were performed over historical (1950-2005) and future (2006-2100, RCP8.5 scenario) periods using the Eco3M-S model, forced by the physical model CNRM-RCSM4. The historical simulation was initialized using the MEDAR-MEDAtlas database (Manca et al., 2004) as in Kessouri (2015). The final state of this simulation was then used to initialize the scenario simulation. Terrestrial, atmospheric inputs and nutrient concentrations in the Atlantic have been kept constant from 1950 to 2100. An average of nutrient loads over the period 1960-2000, based on regional estimates by Ludwig et al. (2010), was imposed at the mouths of the 173 rivers considered. The atmospheric deposition of dissolved inorganic nitrogen has been determined on the basis of studies by Ribera d'Alcalà (2003), Powley et al. (2017), and Richon et al. (2018); and the phosphate deposition has been derived from a climatology of Saharan dust deposits simulated by the regional model ALADIN-Climat (Nabat et al., 2015; Richon et al., 2018). Nutrient profiles applied in the Atlantic buffer zone were prescribed using monthly profiles from the World Ocean Atlas 2009 climatology (Garcia et al., 2006).

\section{Assessing Climate Change Effects on Mediterranean Marine Biodiversity With OSMOSE}

We used OSMOSE to project potential changes in biomass and catch of high trophic level species (fish, cephalopods, and crustaceans) by the middle (2021-2050) and end of the 21st century (2071-2100) under the high emission RCP8.5 scenario and current fisheries exploitation level (fishing mortality and size of recruitment were held constant). For each future time period (each spanning 30 years), climate and biogeochemical forcing variables were used as climatologies. All the parameters relating to growth, reproduction, predation or mortality of the modeled species were kept similar between scenarios (except predation mortality which varies dynamically and is an outcome of the model). Given the inherent stochasticity of OSMOSE (the main source of stochasticity lies in the species movement within their habitat and the order at which schools interact (through predation) (Moullec et al., 2019), ten replicated simulations by time period were run and averaged. For each of the three time slices (current, 2021-2050 and 2071-2100), simulations were run for 110 years to ensure sufficient spin-up time and only the last 10 years were averaged to analyze the outputs.

To assess climate change impacts on Mediterranean marine biodiversity, a range of output indicators, including total biomass and catch, were analyzed and compared between the current (2006-2013) and future time periods, 2021-2050 and 2071-2100. Trophic indicators were used to assess potential changes in food web structure and functioning: the Mean Trophic Level of the community (MTLc) (Pauly et al., 1998), the High Trophic Indicator (HTI), which represents the proportion of biomass of predators with a trophic level higher or equal to 4 (Bourdaud et al., 2016). The percentage of biomass within different body size-classes $(<10 \mathrm{~cm} ; 10-20 \mathrm{~cm} ; 20-30 \mathrm{~cm} ; 30-40 \mathrm{~cm}$, and $>40 \mathrm{~cm}$ ) was also used to assess climate change impacts on ecosystem structure. Note that the proportion of total biomass that exceeds a threshold length of $40 \mathrm{~cm}$ is equivalent to the Large Fish Indicator (LFI) that is a key indicator monitored in European waters to assess ecosystem impacts of fishing (Modica et al., 2014). All analyses were performed using $\mathrm{R}$ version 3.5.1 (R Core Team, 2018).

\section{RESULTS}

\section{Current and Future Environmental Conditions}

During the historical period (1970-2005), CNRM-RCSM4 estimated that the annual mean Sea Surface Temperature (SST; 0-50 m depth) and the mean Sea Surface Salinity (SSS; 0-50 m depth) of the Mediterranean Sea were $17.6^{\circ} \mathrm{C}\left( \pm 1.3^{\circ} \mathrm{C}\right.$; standard deviation) and 37.9 practical salinity unit ( \pm 0.7 PSU; standard deviation), respectively (see Supplementary Figures S1, S2). The Gulf of Lions and the Northern Adriatic Sea were identified as the coolest areas (with a mean SST of 15.3 and $15.6^{\circ} \mathrm{C}$, respectively) while the Levantine Sea and the Gulf of Gabes were identified as the warmest areas (with mean SST of 19.4 and $18.9^{\circ} \mathrm{C}$, respectively). Under the RCP8.5 emission scenario, CNRMSRCSM4 projected a spatially homogeneous warming and a more regionally contrasted salinification of the Mediterranean Sea by the end of the century (Supplementary Figures S1, S2). The Mediterranean Sea was projected to warm by $0.9^{\circ} \mathrm{C}\left( \pm 0.05^{\circ} \mathrm{C}\right)$ globally for $2021-2050$ and by $2.51^{\circ} \mathrm{C}\left( \pm 0.16^{\circ} \mathrm{C}\right)$ for $2071-2100$ with respect to 1970-2005. By the end of the century, the projected increase in mean SST was highest in the Levantine Sea and the Western Ionian Sea $\left(+2.7^{\circ} \mathrm{C}\right)$. In parallel, the SSS is expected to increase, with marked regional differences, by 0.13 
PSU ( \pm 0.13 PSU) for the 2021-2050 period and to come back to its current global climate value ( $\pm 0.01 \mathrm{PSU})$ for the 2071-2100 period (Supplementary Figures S1, S2). By 2021-2050, the SSS of the Adriatic Sea was projected to increase by 0.35 PSU while that of the Alboran Sea (next to the Strait of Gibraltar) was projected to decrease by 0.1 PSU. By the end of the century (2071-2100), due to the evaporation increase, the precipitation decrease and the strong decrease in the Po freshwater input, SSS was found to increase by 0.55 PSU in the Adriatic Sea, while due to changes in Atlantic waters inflow characteristics, SSS may decrease by 0.65 PSU in the Alboran Sea.

\section{Current and Future Plankton Productivity}

Under RCP8.5, projections of Eco3M-S showed a relative stability of the overall biomass of phytoplankton by mid-century (2021-2050) compared to the current period (Supplementary Figure S3). This global stability conceals a biomass increase of the smallest groups of phytoplankton such as the picoand nano-phytoplankton (by 10 and 4\%, respectively) and a decrease of ca. $6 \%$ in the biomass of the largest size group (i.e., microphytoplankton). The biomass of zooplankton followed similar trends with a slight increase of the smallest size groups (3 and $4 \%$ increase for nano- and micro-zooplankton, respectively) and a very low increase of biomass of $1 \%$ for the mesozooplankton group (Supplementary Figure S4). Significant changes of primary and secondary productions appeared toward the end of the century. Projections showed an overall increase of phytoplankton biomass at the whole Mediterranean scale, due to a large gain of biomass for the smaller sized organisms (pico- and nano-phytoplankton biomass were projected to increase by 28 and $13 \%$, respectively), but a decrease by $15 \%$ for microphytoplankton biomass was expected (Supplementary Figure S5). Likewise, climate changes are projected to favor the most opportunistic zooplankton class in the model with an increase of biomass of 8,19 , and 7\% for nano-, micro-, and meso-zooplankton groups, respectively (Supplementary Figure S6). For both time periods, changes of plankton productivity were spatially heterogeneous and a more pronounced increase of plankton productivity was projected in the eastern basin, compared to the western part.

\section{Current and Future Species Geographic Distribution}

By 2021-2050, under the RCP8.5 scenario, the geographic range of 12 species (12.4\%) was projected to shrink whereas 16 species $(16.5 \%)$ were projected to increase their geographic range (Supplementary Table S3). By the end of the century (2071-2100), while the number of species gaining in geographic range remained relatively stable (14 species), the proportion of species projected to lose suitable habitat increased by fifty percent (24 species) to reach almost a quarter of the Mediterranean modeled fauna. Among the 24 "losers," Micromesistius poutassou was expected to contract its geographic range by $95 \%$, with a distribution becoming extremely fragmented. The projections reported high variations in the size of species distribution areas through time. By 2021-2050, the average loss and gain in species distributional range were 22 and 32\%, respectively, whereas by 2071-2100 they were 26 and 174\%, respectively. Gains in range size were mainly due to some thermophilic alien species (i.e., Etrumeus teres, Caranx crysos, Sphyraena viridensis, Stephanolepis diaspros, and Upeneus moluccensis) originally restricted to small areas of the Mediterranean Sea and which found, with changes in environmental conditions, new suitable habitats across the basin. Some species of high commercial interest exhibited contrasted evolution of their range between the two time periods. For instance, European hake (Merluccius merluccius) was expected to gain up to $9 \%$ of potential suitable climatic habitat at first (2021-2050), but then to experience a range reduction of $15 \%$ toward the end of the century (2071-2100).

\section{Projected Changes in Biomass of the High Trophic Level Species}

At the Mediterranean scale, considering projected changes of plankton productivity and species geographic distribution under the high emission scenario RCP8.5, climate change is projected to increase the total biomass of all high trophic levels species by 5 and $22 \%$ by 2021-2050 and 2071-2100, respectively (Figures 2A,B). Changes in biomass globally reflected the changes in primary and secondary productions. For both future periods, the gain in biomass was more important in the eastern basin and especially in the Levantine Sea (Figure 2A). In this area, some thermophilic exotic species, here qualified as "winner" species, such as E. teres, Saurida undosquamis, $S$. diaspros, and $U$. moluccensis, benefited from an increase in their geographic range, as well as an increase in plankton productivity, especially for the planktivorous fish species such as E. teres. Biomass of this latter species has been found to potentially boom 70 -fold by the end of the 21 st century while the biomass of C. crysos or S. undosquamis could be multiplied by 2 and 48 , respectively.

Future changes in biomass are expected to slightly differ depending on the vertical distribution of species in the water column (Figure 2B). By the middle of the century, the biomass of demersal species could increase by ca. 3\% whereas benthic biomass could decrease by $2 \%$. Pelagic species, with an increase in biomass of $7 \%$, could benefit the most from the increase in plankton productivity (Figure 2B). Nevertheless, the global gain of biomass by 2021-2050 masked some loser species. For instance, biomass could be reduced by $6 \%$ for Dicentrarchus labrax, by $4 \%$ for M. merluccius, by $20 \%$ for Spondyliosoma cantharus, by $6 \%$ for Octopus vulgaris, by $7 \%$ for Scomber scombrus, and by $5 \%$ for Diplodus vulgaris. In addition, three species, for which a reduction in range had not been predicted by niche models, were projected to be on the verge of collapse, with a decrease of more than $50 \%$ in their biomass, and four species were projected to become quasi extinct with a $90 \%$ decrease in their biomass by 2021-2050.

By the end of the 21st century, with a projected increase of ca. 3\%, the biomass of demersal species could remain 


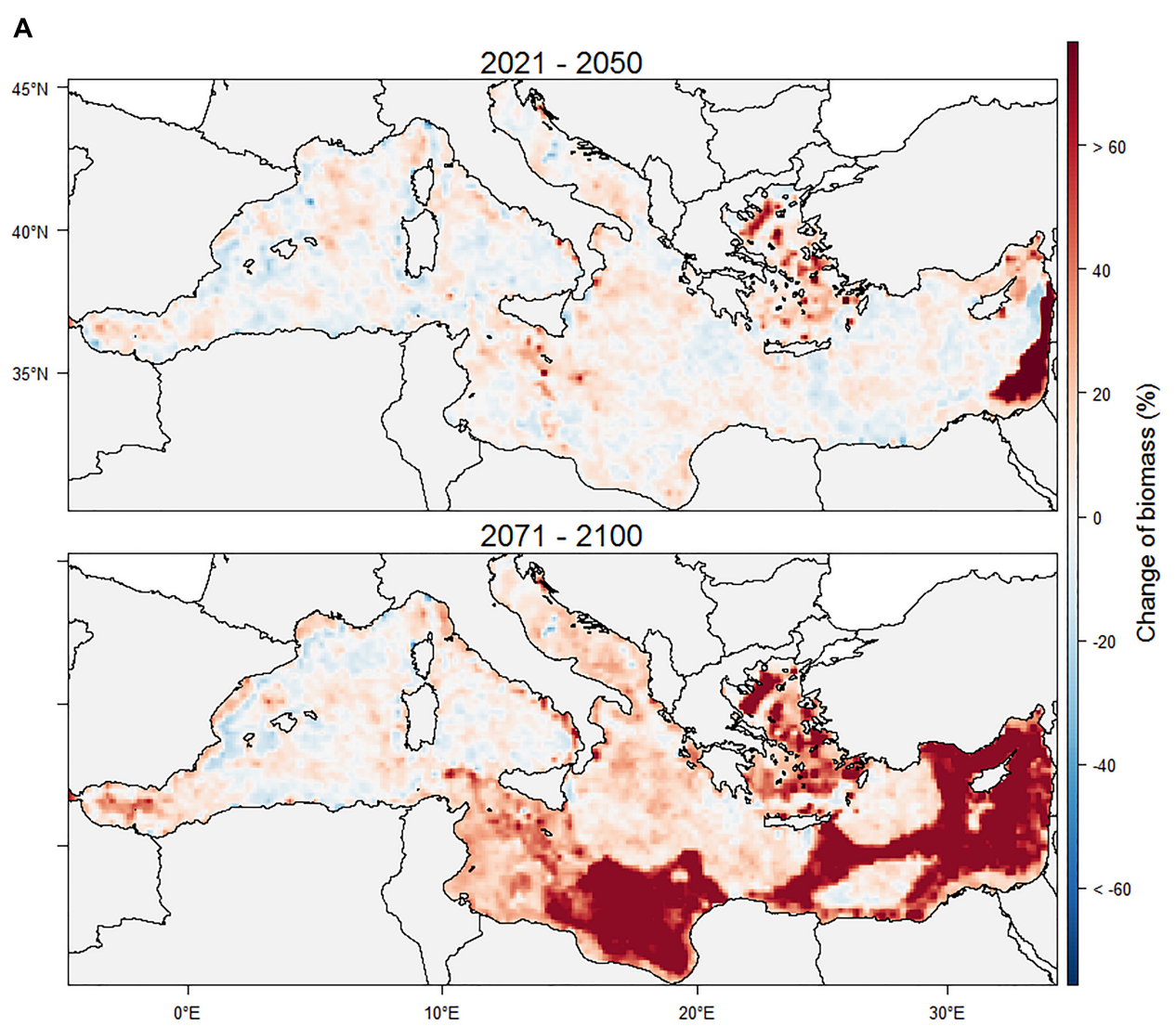

B
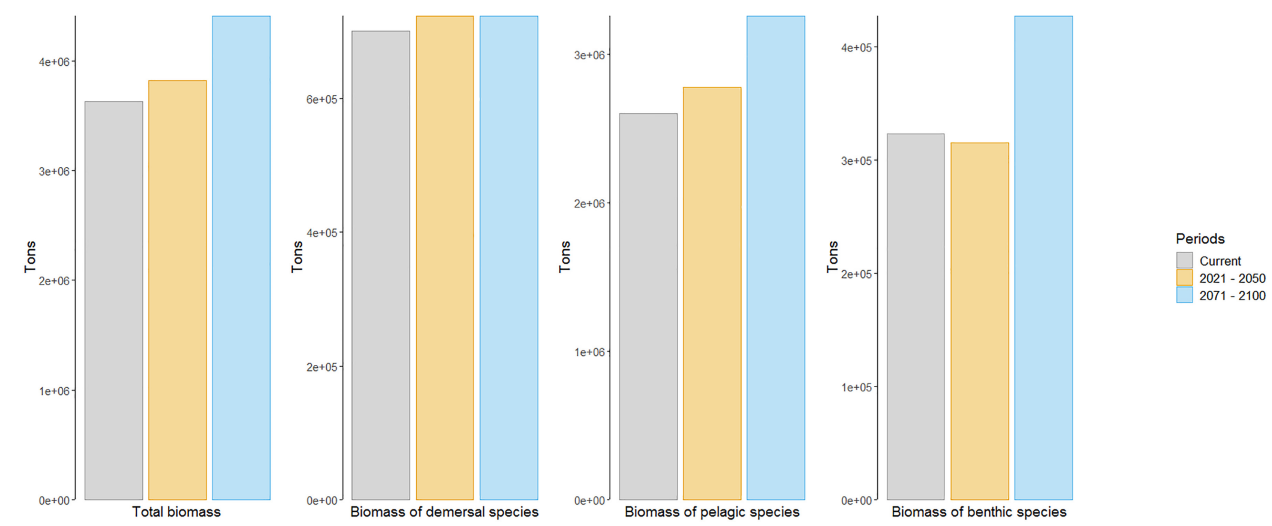

FIGURE 2 | (A) Projected relative change in biomass between the current period (2006-2013) and the future (2021-2050 top; 2071-2100, bottom) under the emission scenario RCP8.5. (B) Total biomass and biomass of pelagic, demersal, and benthic species for current (2006-2013) and future time periods (2021-2050, top; 2071-2100, bottom) under emission scenario RCP8.5.

stable compared to 2021-2050 (Figure 2B). However, the biomass of pelagic species was projected to increase by more than $25 \%$ and that of benthic species by $32 \%$ compared to the baseline period. Despite the global increase, the biomass of some species of high commercial interest are expected to decline, for instance, M. merluccius and Scomber scombrus biomass could decrease by 26 and 15\%, respectively. Among the losers, ten species were projected to suffer from a drastic reduction exceeding 50\% of their current biomass, and among these species, five were projected to become extinct, following a reduction exceeding $90 \%$ of their current biomass. On the other hand, the biomass of other species of commercial interest, mainly pelagic species such as Engraulis encrasicolus, Coryphaena hippurus, Thunnus thynnus, or Sardina pilchardus, are expected to increase by $35,34,9$, and $6 \%$, respectively. 

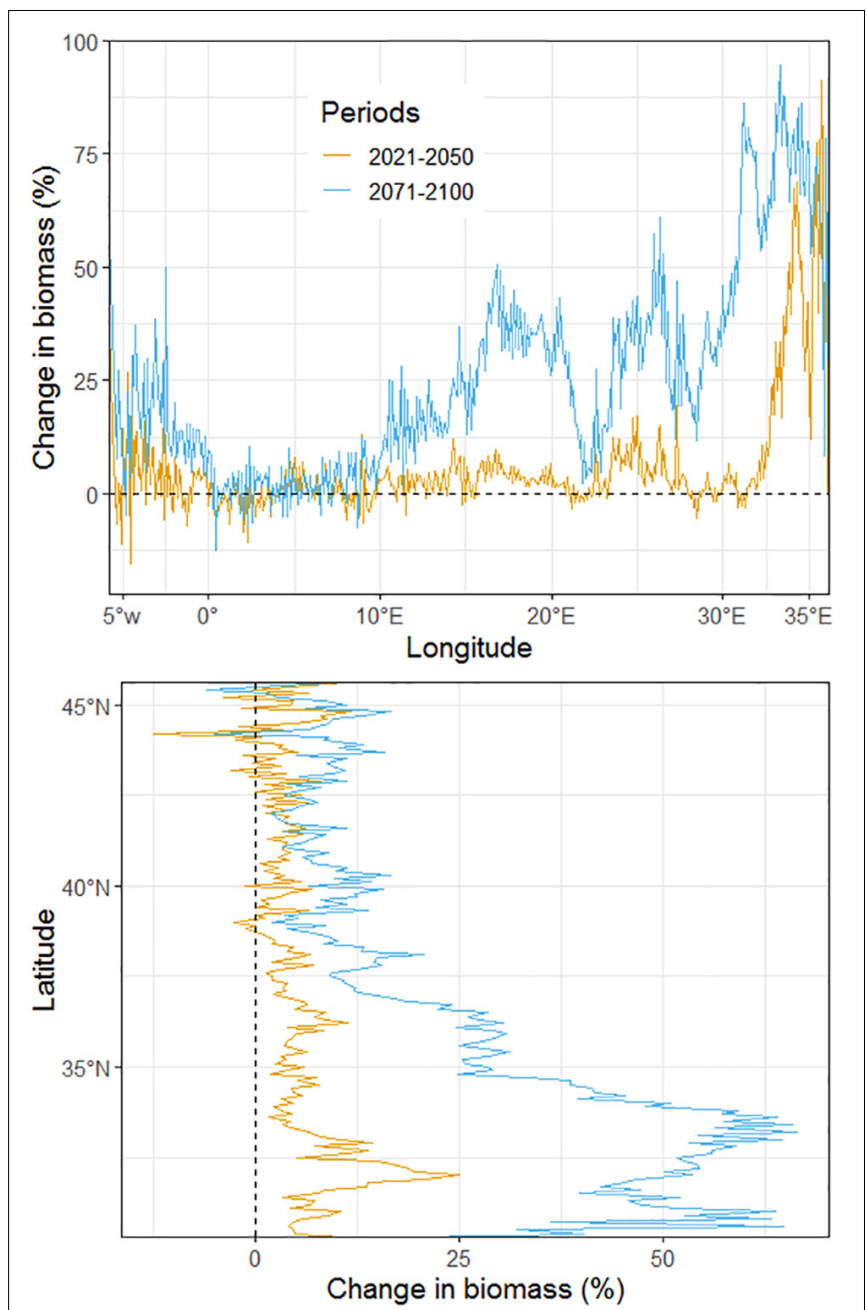

FIGURE 3 | Projected longitudinal and latitudinal changes in total biomass (all high trophic levels species confounded) between current (2006-2013) and future periods (2021-2050 in yellow; 2071-2100 in blue) under emission scenario RCP8.5. The dotted line indicates no change in biomass.

Regional contrasts in biomass changes can be observed in the projections (Figure 3). By the middle of the century, along the longitudinal gradient, from $0^{\circ}$ to $32^{\circ} \mathrm{E}$, total biomass is expected to increase very moderately by ca. $2.5 \%$. Changes could likely be more pronounced in the most western part, between $0^{\circ}$ and $6^{\circ} \mathrm{E}$, and in the most eastern part of the Mediterranean Sea with a total biomass gain of up to 27 and 90\%, respectively. Overall, by the end of the century, projected changes in biomass showed similar spatial patterns, but with higher magnitudes of changes (Figure 3). With the continued northward and westward expansion of the ranges of some exotic species and higher planktonic productivity toward the end of the 21st century, biomass gain could continue and reach up to $+50 \%$ between $15^{\circ} \mathrm{E}$ and $21^{\circ} \mathrm{E}$ (South Ionian Sea) and up to $+61 \%$ in the Levantine Sea $\left(26^{\circ} \mathrm{E}\right)$. Analysis of biomass changes along the latitudinal gradient revealed an increasing trend of biomass from north to south (Figure 3). As with longitudinal changes, projected changes of biomass by 2021-2050 and 20712100 showed a similar pattern but of different magnitude. Between $30^{\circ} \mathrm{N}$ and $35^{\circ} \mathrm{N}$, the increase in biomass is projected to reach up to $25 \%$ by $2021-2050$ and up to $66 \%$ by $2071-2100$.

By mid-century, changes in biomass were rather homogeneous over the continental shelf and the offshore area and along longitudinal and latitudinal gradients except for some local zones. For instance, between $5^{\circ} \mathrm{E}$ and $7^{\circ} \mathrm{E}$, a decrease in biomass of up to $39 \%$ was projected on the continental shelf (mainly Balearic island and Algerian coastal zone) while a relative stability in biomass was projected in the offshore area (Figure 4). By the end of the century, the continental shelf and the offshore area exhibited more pronounced differences along longitudinal and latitudinal gradients, especially in the easternmost regions where biomass increases were greater in offshore areas than on the continental shelf. Along the latitudinal gradient, between $36^{\circ} \mathrm{N}$ and $45^{\circ} \mathrm{N}$, biomass increases were found to be generally higher on the continental shelf than in the offshore area. This trend is reversed at latitudes below $36^{\circ} \mathrm{N}$ where the increase in biomass was much higher offshore.

\section{Projected Changes in Size Structure}

The analysis of the proportion of biomass within different size-classes showed no substantial change by 2021-2050 but a very slight increase $(+3 \%)$ of medium-sized individuals $(20-30 \mathrm{~cm})$ and a slight decrease $(-6 \%)$ of very large-sized individuals $(>40 \mathrm{~cm}$ ) (Figure 5). By the end of the 21st century, the proportions of biomass in the two smallest sizeclasses $(<10 \mathrm{~cm} ; 10-20 \mathrm{~cm})$ were projected to increase by 3 and 7\%, respectively, while the proportions of biomass of medium-sized individuals, large-sized individuals and very largesized individuals were projected to decrease by 8,15 , and $15 \%$, respectively (Figure 5).

\section{Projected Changes in Trophic Indicators}

The two trophic indicators, namely the High Trophic Indicator (HTI) and the Mean Trophic Level of the community (MTLc) showed the same downward trend for the two future periods (Figure 6). The HTI is projected to decrease by 5 and $15 \%$ by 2021-2050 and 2071-2100, respectively. Logically linked to the increase in the biomass of pelagic species (mainly planktivorous fish species), the MTLc is predicted to decrease by 0.4 and $2 \%$ by the middle and end of the 21 st century, respectively.

\section{Projected Changes of Catch}

Annual fisheries catches simulated by OSMOSE amounted to $788043 \mathrm{t}$ for the current period. By 2021-2050, under RCP8.5 and "business as usual" fisheries management, the total projected catches in the Mediterranean Sea are expected to remain stable (Figures 7A,B). By the end of the century, the total catches could rise by ca. $7 \%$ to reach 840008 t. However, this projected increase 

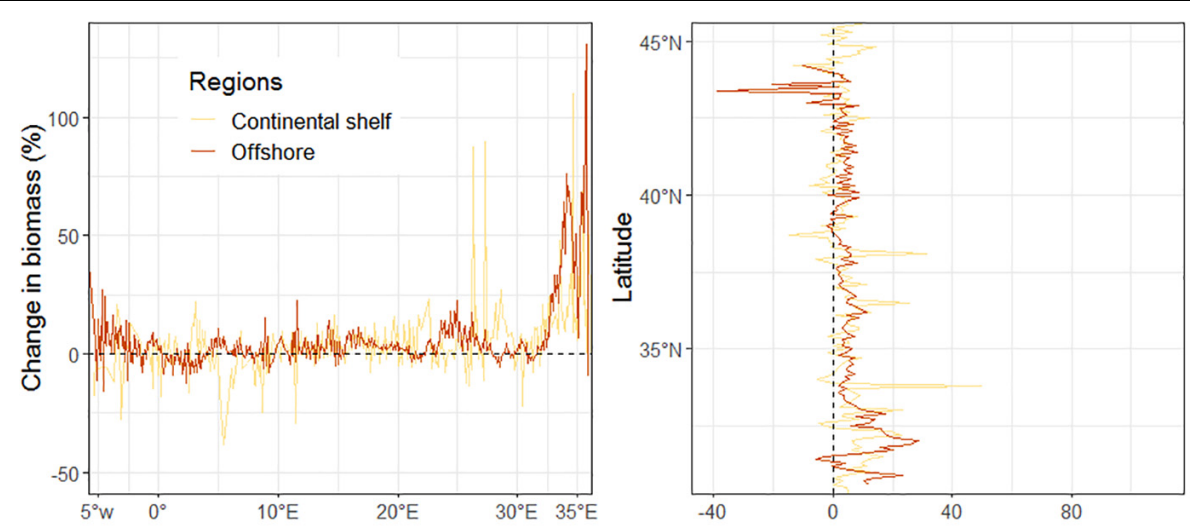

$2021-2050$
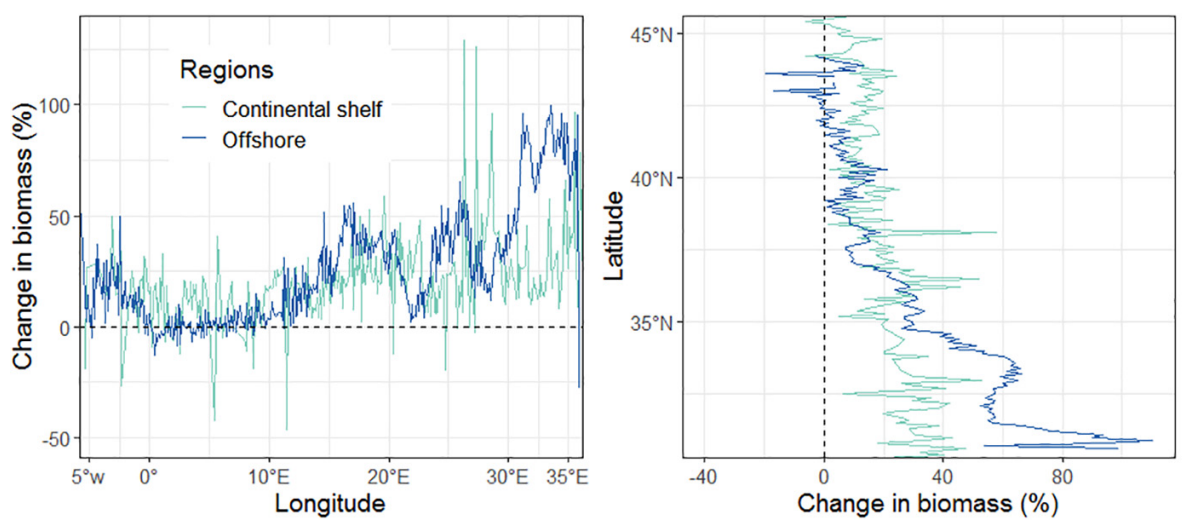

$2071-2100$

FIGURE 4 | Projected relative changes in total biomass (all high trophic levels species confounded) between the current (2006-2013) and future periods (2021-2050, top; 2071-2100, bottom) in continental shelf (depth $\leq 200 \mathrm{~m}$ ) and offshore (>200 m) under emission scenario RCP8.5. The dotted line indicates no change in total biomass.

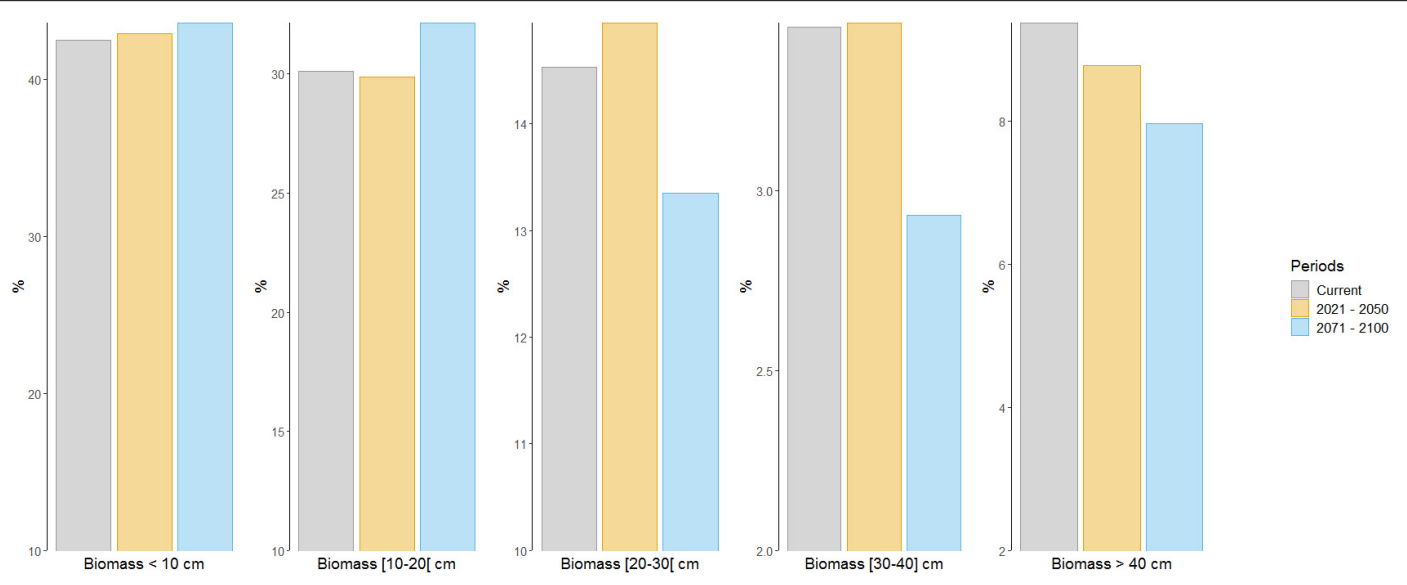

FIGURE 5 | Proportion of total biomass within different size-classes for current (2006-2013; gray bars) and future time periods (2021-2050, yellow bars; 2071-2100, blue bars) under emission scenario RCP8.5.

hides a substantial heterogeneity between species and between management units (i.e., Geographical Sub-Areas; GSA).

By the middle of the century, simulated catches showed either a downward trend in most GSAs (up to $-22 \%$ in South Tyrrhenian Sea (GSA 10), $-9 \%$ in Balearic Island and in Southern Adriatic Sea (GSA 5 and 18, respectively) or $-7 \%$ in South of Sicily (GSA 16), or a relative stability (i.e., increase of less than 2\%) (Figure 7A). As with the projections of total biomass, it was in the Levantine Sea (GSA 27) that catches are expected to increase the most (up to $+42 \%$ ), mainly due to the biomass explosion of two exotic species (E. teres and S. undosquamis). In the Alboran Sea (GSA 1 and 3), Northern Spain (GSA 6), Gulf of 

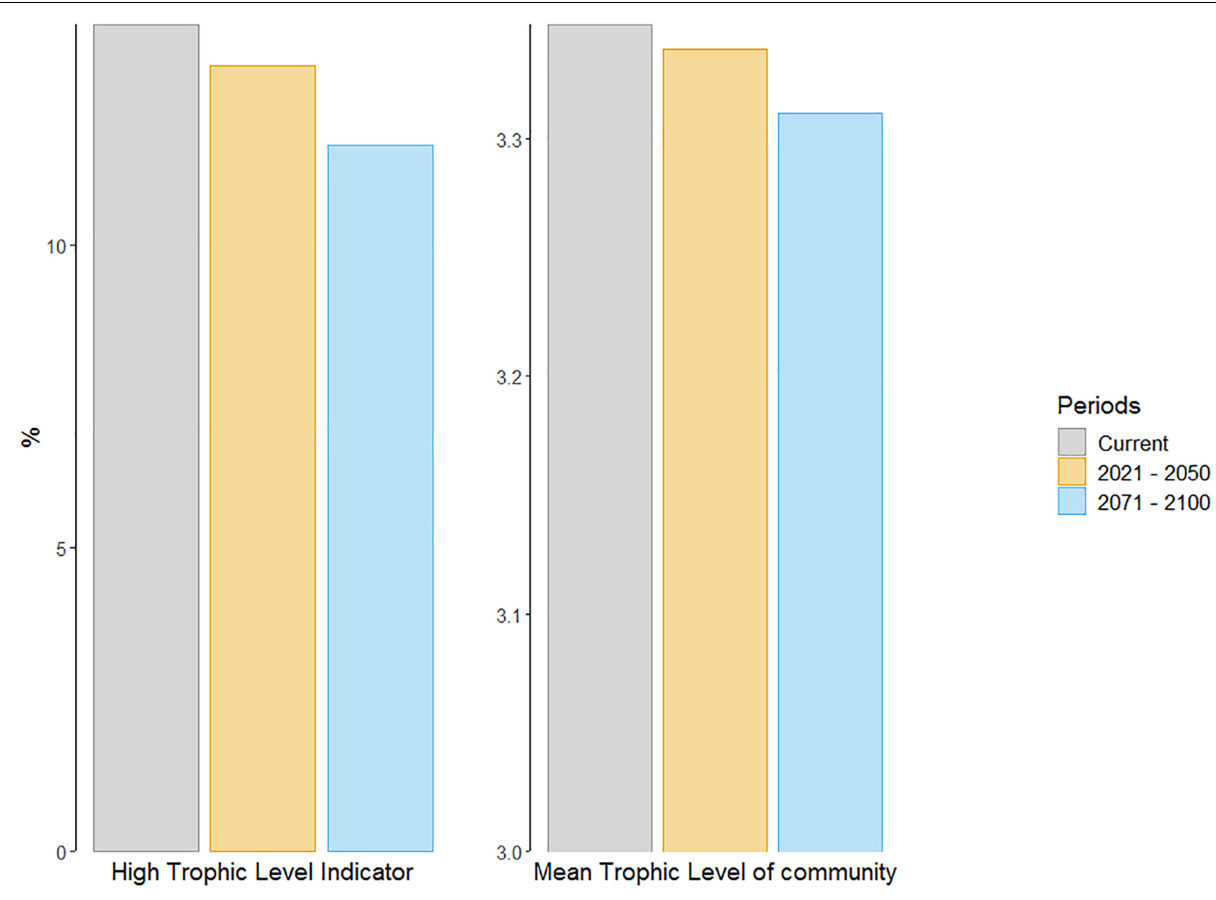

FIGURE 6 | Trophic indicators values (HTI and MTLc) for current (2006-2013; gray bars) and future time periods (2021-2050, yellow bars; 2071-2100, blue bars) under emission scenario RCP8.5.

Lions (GSA 7), and Aegean Sea (GSA 22), catches were projected to increase by between 7 and $9 \%$ mainly due to an increase in the catch of small pelagic species such as E. encrasicolus ( $+6 \%)$.

The spatial patterns of catch are projected to change radically by the end of the century (Figure 7A). Three regions could be distinguished: the western Mediterranean, the eastern Mediterranean and the Adriatic Sea. By 2071-2100, in all the western Mediterranean Sea, catches are expected to decrease by between 2 and 22\% ( $-22 \%$ in Balearic Island, $-19 \%$ in the southern Tyrrhenian Sea, $-14 \%$ in Northern Spain and $-13 \%$ in Algerian and Tunisian waters, for instance). In the Adriatic Sea, catches were projected to remain stable with an increase of ca. $2 \%$ in the northern part (GSA 17) and a decrease of ca. $3 \%$ in the southern part (GSA 18). By contrast, due to a large increase of catches of some exotic species in the eastern Mediterranean Sea, all the GSAs of this part of the basin were projected to experience an increase in catch by between $8 \%$ (eastern Ionian Sea) and 47\% (Cyprus Island).

Depending on the vertical distribution of species, differential responses to future climate change could be observed (Figure 7B). Projections suggested a moderate to low increase in the catches of demersal and pelagic species, of 2 and $0.6 \%$, respectively, and a decrease in the catches of benthic species of ca. 10\% by 2021-2050 (Figure 7B). Among demersal catches, those of $M$. merluccius, one of the main exploited species, are expected to decrease by $4 \%$ while Boops boops catches are expected to increase slightly by $2 \%$. Among pelagic species, E. encrasicolus catches were projected to increase by $6 \%$ while Sarda sarda catches were projected to decrease by $7 \%$. Finally, among benthic species, Mullus barbatus catches are expected to increase by $3 \%$ while Mullus surmuletus catches were projected to decrease by up to $2 \%$. By 2071-2100, some trends are expected to be reversed or amplified with a reduction in demersal catches of about $2 \%$, an increase in pelagic catches of $9 \%$ and a substantial increase in the catches of benthic organisms by nearly 16\% (Figure 7B). Among the main exploited species, M. merluccius catches are expected to fall by $26 \%$ compared to current catches, while E. encrasicolus catches could increase by nearly $35 \%$ and Mullus barbatus catches are expected to decrease by just over $3 \%$. The increase in catches of thermophilic and/or exotic species is the main cause of the overall increase in projected catches by the end of the century. According to the business-as-usual fishing mortality scenario considered in this study, the catches of exotic species modeled in OSMOSE are expected to increase by an average factor of 40 .

\section{DISCUSSION}

\section{Advances, Limits, and Perspectives}

Under climate change, the Mediterranean climate is getting warmer and drier, causing large-scale changes in the Mediterranean Sea and associated marine biodiversity with significant implications for marine ecosystems and the livelihoods that they support (Somot et al., 2006; Coll et al., 2010; Macias et al., 2014, 2015; Adloff et al., 2015; Marbà et al., 2015; Ramírez et al., 2018). Many studies have already shown, assessed or modeled potential impacts of climate change on Mediterranean marine ecosystems (Galil, 2000; Giorgi and Lionello, 2008; Lejeusne et al., 2010; Albouy et al., 2013; Cramer et al., 2018). Most of them focused 


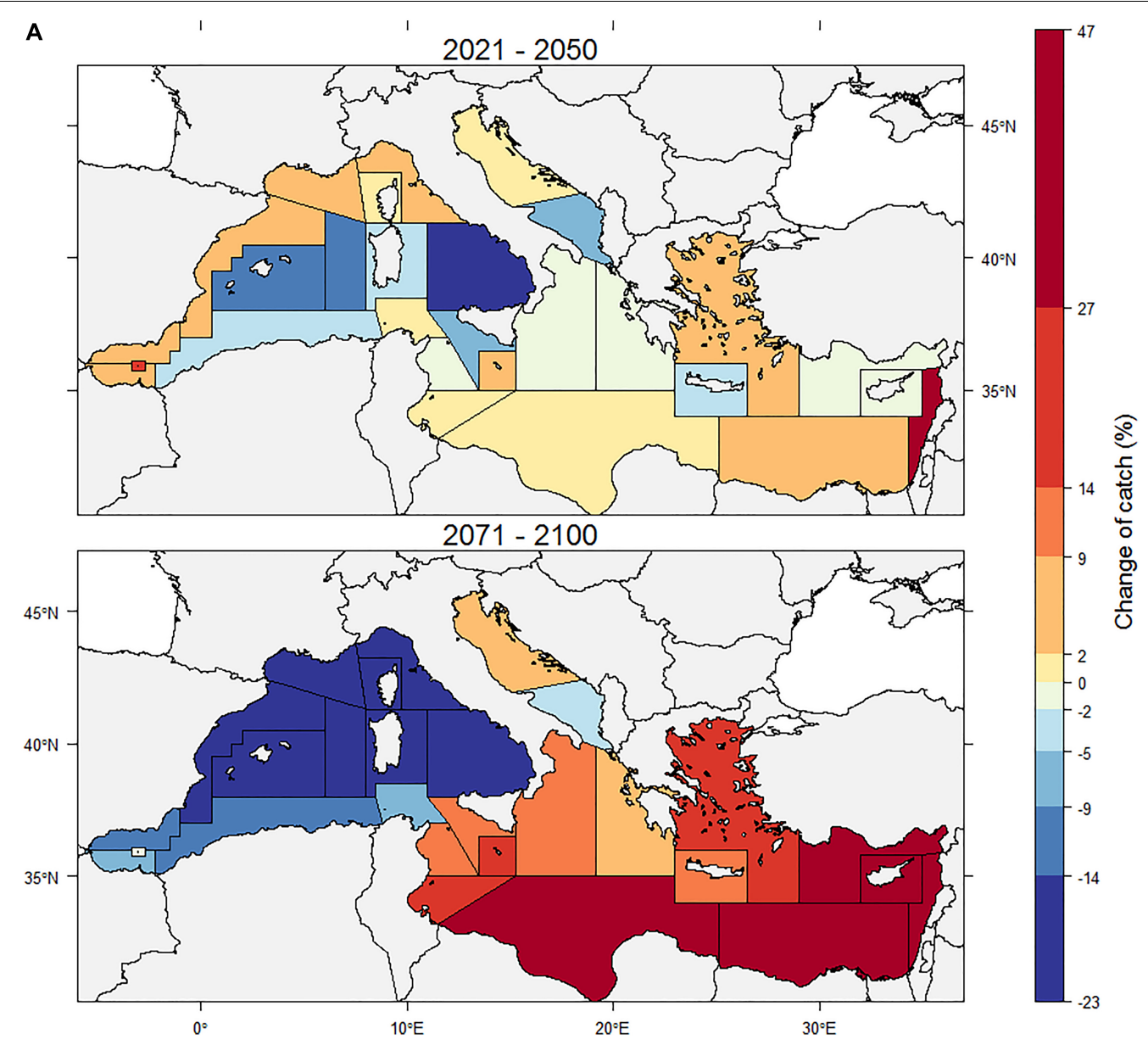

B
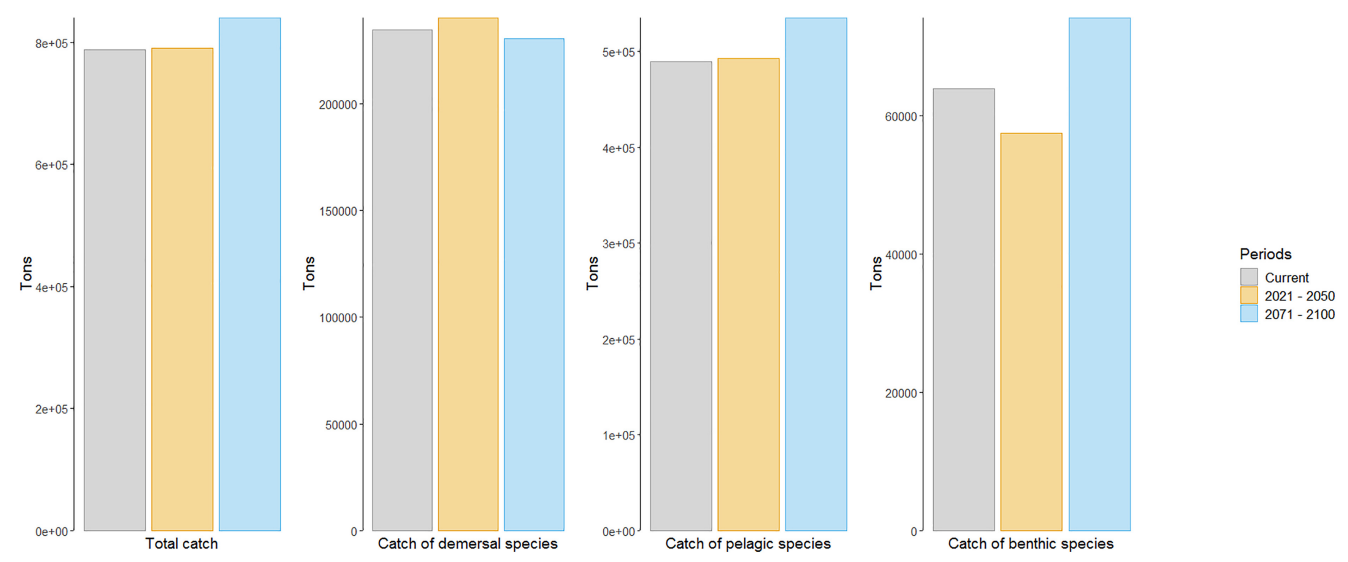

FIGURE 7 | (A) Relative changes in catches (all exploited species confounded) by Geographical Sub-Area (GSA) between the current period (2006-2013) and the future (2021-2050, top; 2071-2100, bottom) under emission scenario RCP8.5. (B) Total catch and catch of demersal, pelagic, and benthic species for current (2006-2013) and future time periods (2021-2050, top; 2071-2100, bottom) under emission scenario RCP8.5.

on a specific compartment, whether biotic (e.g., Ben Rais Lasram et al., 2010; Benedetti et al., 2018) or abiotic (e.g., Richon et al., 2019). Most of them were conducted at local scales, at the scale of the continental shelf (e.g., Albouy et al., 2014; Hattab et al., 2014) or for specific ecosystems (e.g., Libralato et al., 2015; Corrales et al., 2018). To our knowledge, the 
present study is the first attempt to project the effects of climate change at the whole Mediterranean scale in an integrated way, considering explicit and consistent changes in regional climate, ocean dynamics, nutrient cycle, plankton production, shifts in species distributions, their life cycles and their trophodynamic interactions. Nearly one hundred high trophic level species were explicitly modeled in the modeling chain set for this study. Despite the significant progress that our end-to-end modeling chain represents to project the potential effects of climate change on populations, communities, and ecosystems structure, some limits still remain in the model projections as the results presented here are subject to several sources of uncertainty.

The first uncertainty lies in the choice of specific physical (RCSM4) and biogeochemistry (Eco3M-S) models to project the future evolution of the regional climate, the Mediterranean Sea physics and the plankton productivity that were used to force the high trophic level model OSMOSE. These choices were constrained by the existence of a very limited number of consistent hydrodynamic-biogeochemical projections developed at the Mediterranean scale, at high resolution, and for which the most up-to-date greenhouse gas emission scenarios (i.e., IPCC RCPs) were implemented. The low trophic model Eco3M-S simulated a significant increase in phytoplankton (1 and $11 \%$ in the western and eastern sub-basins, respectively) and zooplankton (5 and 15\% in the western and eastern sub-basins, respectively) biomass, with an increasing contribution of small phytoplankton by the end of the 21 st century. The simulated evolution of phytoplankton community structure in response to the extension of the stratified period is consistent with previous observational and modeling studies (Karl et al., 2001; Bopp et al., 2005; Morán et al., 2010; Herrmann et al., 2014). The increase of total plankton biomass obtained can be attributed to an increase in metabolic processes due to surface water warming, as well as by an increasing water inflow and associated nutrient supply at the Gibraltar Strait, which accelerated after the 1950s. Primary production, grazing and recycling processes are temperature sensitive in Eco3M-S model (Auger et al., 2011). Their rates are influenced directly by temperature through an Eppley-type formula (Eppley, 1972) of the form of $Q_{10}^{\frac{\left(T-T_{1}\right)}{T_{2}}}$ (where $Q_{10}$ and $T$ were empirical constants, $T_{1}=14$ and $T_{2}=10$ ). Eco3M-S results are consistent with previous studies in which integrated primary production increased with the direct effect of temperature and an increasing stratification (Sarmiento et al., 1998; Karl et al., 2001; Taucher and Oschlies, 2011; Herrmann et al., 2014). In particular, Taucher and Oschlies (2011) showed that the response of primary production to climate change strongly varies according to the temperature sensitivity in model equations of primary production and recycling processes, with a change of direction in primary production evolution if temperature influence is directly taken into account or not. However, other studies obtained a decline in primary production due to reduced vertical nutrient supply into the photic layer with the weakening of vertical mixing (Steinacher et al., 2010; Bopp et al., 2013). Here, the direct effect of temperature prevailed over the decline of vertical nutrient supply. This is consistent with the study of Herrmann et al. (2014) who obtained no significant change in phytoplankton biomass, but significant increase in zooplankton biomass and primary production in the north-western Mediterranean Sea where a weakening of deep convection was projected under the SRES A2 scenario. This evolution is, however, in contrast to that simulated by Richon et al. (2019) with a decline in zooplankton biomass for the 21st century in the whole Mediterranean basin, under the SRES A2 scenario. The discrepancies of Eco3M$S$ results with the latter study may be partly explained by differences in nutrient supply at the Gibraltar Strait. In our study, the annual input of nutrients at the Gibraltar Strait was increasing over the whole future period. Thus, the impacts of climate change on the Mediterranean Sea could be modulated by the choice of the near-Atlantic surface water evolution, an uncertain element in General Circulation Models (Adloff et al., 2015). Furthermore, in this study variations over the last decades and future changes in nutrient river loads were not taken into account in the Eco3M-S simulation as no consistent projections until the end of the 21st century exist, partly due to the difficulties of predicting socio-economic decisions (Ludwig et al., 2010). However, the study of Lazzari et al. (2014) showed that an increase in nutrient terrestrial inputs could lead to an increasing primary production close to river mouths. More complex scenarios will be assessed with the Eco3M-s model in future works. Outputs trends of Eco3M-S, related to the structure and parameterization characteristics of the model, influence the overall trends of our results. One approach to overcome individual model uncertainties and limitations would be to force OSMOSE with an ensemble of several hydrodynamicbiogeochemical coupled models when they are available for the Mediterranean sea to estimate mean future trends and associated inter-model spread (Lotze et al., 2018).

Despite the many ecological processes integrated explicitly in OSMOSE, a number of simplifications were mandatory to render the parameterization, the calibration of the model and the simulations tractable. For example, the effects of changes in temperature, oxygen content or $\mathrm{pH}$, on the ecophysiology as well as the feeding and intrinsic mortality rates and behavioral capabilities of marine organisms were not considered in our projections (Pauly, 2010; Cheung et al., 2011, 2013). Yet, such ecophysiological changes could affect life history traits, life cycles and key ecological processes such as predator-prey interactions (Cheung et al., 2013; Mazumder et al., 2015; Allan et al., 2017) and thus could dampen or exacerbate the projected effects of climate change on ecosystem structure and functioning (e.g., Beaugrand and Kirby, 2018). Likewise, OSMOSE does not consider the adaptive potential, whether phenotypic or evolutionary, of marine organisms to climate change stressors. When the magnitude and velocity of changes are moderate, adaptation can buffer substantially the effects of climate change on marine organisms and ecosystems (Crozier and Hutchings, 2014; Boyd et al., 2016; Beaugrand and Kirby, 2018).

In our study, a source of uncertainty also lies in the choice, for methodological reasons, to not model and consider adaptive behavior of fishermen to potential changes in species abundance and distribution. We caution that a constant fishing mortality scenario, implying no changes in fishing effort, technology, management and conservation, is simplistic and could influence 
projected biomass and catch trends (Lotze et al., 2018) but this type of scenario allows to focus and isolate climate change effects on marine animal biomass (Bryndum-Buchholz et al., 2019). As mentioned by Cheung et al. (2010), expliciting changes in fishing dynamics is yet important in evaluating climate change impacts and needs to be incorporated in future analyses. Our results are most likely conservative with regard to the projections of biomass and catches toward the end of the century. Climate change is only one component of global change. In the Mediterranean Sea, perhaps more than elsewhere, climate change is likely to act in synergy with other increasing anthropogenic disturbances such as pollution, eutrophication, overexploitation of resources and habitat modification and destruction, all of which playing a major role in altering the structure and functioning of ecosystems (Crain et al., 2008; Ben Rais Lasram et al., 2010; Pörtner, 2010; Pörtner and Peck, 2010). Our projections did not consider the effects of climate change on key fish habitats such as seagrass beds which act as nurseries for several species of high commercial interest and are already threatened by the rapid warming of the Mediterranean Sea (Hoegh-Guldberg and Bruno, 2010; Marbà and Duarte, 2010; Jordà et al., 2012). Changes in the biomass and geographical distribution of benthic invertebrates were also overlooked in the present study, yet subject to climate change effect and playing a major role in marine biogeochemistry and as food source for many high trophic level species (Hiddink et al., 2015). In addition, a recent study suggests that species distribution models such as those used here for forcing OSMOSE may underestimate the potential spread of invasive species (i.e., Lessepsian species) in the Mediterranean Sea thus leading to an underestimation of the subsequent changes on marine biodiversity (Parravicini et al., 2015). Finally, our projections did not consider potential ingression of Atlantic thermophilic species through the Gibraltar Strait or future settlement of new Lessepsian species through the Suez Canal. With the expected changing environmental conditions by the end of the century, it is most likely that the number of invasive species would increase and may have significant environmental, socio-economic and human health impacts (Ben Rais Lasram and Mouillot, 2008; Mannino et al., 2017).

\section{Structure and Functioning of the Mediterranean Sea Ecosystem Under Climate Change}

Our results show that the high greenhouse gas emission scenario RCP8.5 could lead to a warmer Mediterranean Sea with large variations of salinity conditions toward the end of the 21st century relative to the current period. Such physical changes are expected to change the biogeography of marine organisms with many species expanding or shifting their distribution areas northward and westward. These results are in line with previous studies projecting future spatial distributions of fish species on the Mediterranean continental shelf based on global warming scenarios (e.g., Ben Rais Lasram et al., 2010; Albouy et al., 2012, 2013).

The rise of plankton productivity which is projected by Eco3M-S, mainly in the Alboran Sea and in the southeastern of the Mediterranean Sea, associated with species' range shift, could lead to an increase in biomass and total catches at the Mediterranean scale. Two processes were at the origin of these changes: in the most western part, a higher planktonic productivity allowed, by bottom-up effect, an increase in the biomass of high trophic levels species while in the eastern part, the increase of biomass resulted from a higher planktonic productivity combined to the extension of the distribution areas of thermophilic and/or exotic species. Several studies have already shown the importance of bottom-up control of the Mediterranean ecosystem, generally considered as an oligotrophic system in which productivity of higher trophic levels is under the control of primary productivity (Macias et al., 2014; Lynam et al., 2017). Macias et al. (2014) have for instance demonstrated that during the last 50 years the control of marine productivity in the Mediterranean Sea, from plankton to fish, was principally mediated through bottom-up processes.

The general projected increase in total biomass and catch is principally due to the increase in biomass of small pelagic species and thermophilic exotic species such as the lizardfish $S$. undosquamis and the red-eye round herring $E$. teres, indicating that climate change may produce "winners" and "losers" among Mediterranean species. Winners are clearly thermophilic planktivorous species that are projected to benefit both from an increase of their spatial range and an increase of available food within their range. This favorable association of thermal and trophic niches partly explains the projected evolution of biomass and catch in the Levantine Sea. With another trophic model, Corrales et al. (2018) have also shown that according to climate change scenarios, primary producers and alien fish species were expected to increase the total biomass on the Israeli continental shelf, masking the reductions of the biomass of native species. Based on our integrated modeling, two major processes of change emerged, i.e., the meridionalization and the tropicalization of the Mediterranean Sea during the 21st century, in line with previous findings (e.g., Boero et al., 2008; Azzurro et al., 2011).

According to our results, pelagic species, mainly the small ones, would be the main winners of climate-induced changes. This finding is in accordance with the study of Hattab et al. (2016) who projected that the future food webs of the Gulf of Gabes would be composed of smaller-sized species under a high emission scenario. Smaller sized species, with higher biomass turn-over rate, tend to show larger changes in biomass in response to environmental modifications than larger species with slower biomass turn-over (Brown et al., 2010). It has also been shown that short life span species have benefited from the increase in water temperature in the basin over recent decades (Tzanatos et al., 2014). The increase in the prevalence of low trophic levels and small sized species in the ecosystem by the end of the century may have consequences for both ecosystem functioning and fishing sustainability. Indeed, planktivorous fish species play a central role in food webs and have the potential to initiate complex cascading effects across and between trophic levels thus modifying the trophic functioning of ecosystems. Small pelagic species are more sensitive to climate variability and are subject to more pronounced variability in recruitment under environmental fluctuations (Hsieh et al., 2006; Ottersen et al., 
2006; Perry et al., 2010). With climate change, the mean turnover rate of marine communities is expected to increase due to the relative increase in the proportion of smaller individuals with higher metabolic rates. Thus, by favoring the dominance of shortlived prey populations and strengthening the already important bottom-up control in the basin, climate change might increase the vulnerability of the Mediterranean Sea in synergy with other drivers of change, in a context where fishing pressure has already led to an alteration of the life history traits and demographic structure of exploited populations in the Mediterranean Sea (Colloca et al., 2013, 2017).

There will be winner but also loser species under climate change. In our study, the variation in biomass of loser species can be explained by a shift or contraction of their geographic range leading to spatial mismatch between previously interacting predators and prey. Indeed, climate-induced changes have a strong potential to alter interspecific trophic interactions by modifying the degree to which predators and prey overlap in space and by creating or eliminating prey spatial refugia (Schweiger et al., 2008; Chevillot et al., 2017; Selden et al., 2018). This suggests the importance of considering trophic interactions for improving predictions of biodiversity under climate change (Urban et al., 2016; Selden et al., 2018). As an example, according to our niche models, the geographic range of the European hake ( $M$. merluccius), one of the main commercial species in the basin, could be reduced by $15 \%$ by the end of the century, but when considering trophic interactions, it is a reduction of almost $26 \%$ in its biomass and catches that is projected over this period. Our model results thus suggest that trophic interactions can amplify the direct effects of climate on species as already shown locally by Libralato et al. (2015). In addition, even if species distribution models have the potential to predict the westward and northward expansion of thermophilic species, the increase in biomass in the southeastern Mediterranean Sea could not be anticipated without taking into account trophic interactions in the projections.

Under the high emission scenario RCP8.5, with changes in biogeography and productivity of modeled marine organisms, the species composition of communities and the functioning and structure of Mediterranean marine ecosystems are expected to change significantly. There will likely be a reorganization of species assemblages and associated food webs by the end of the century, both on the continental shelf and in offshore area. Other projections focusing on the continental shelf of the Mediterranean sea showed the same patterns but it is the first time that projections are performed on the offshore area of the basin (Ben Rais Lasram et al., 2010; Albouy et al., 2012, 2013, 2014; Hattab et al., 2014, 2016). Our results suggest an increase in the biomass of low trophic levels species, a higher proportion of small-sized individuals, a decrease in toppredators' biomass as evidenced by the decrease in the HTI indicator and associated decline of the mean trophic level of the community. Several studies have already shown such trends in the Mediterranean Sea (e.g., Ben Rais Lasram et al., 2010; Albouy et al., 2012, 2014; Hattab et al., 2014, 2016; Libralato et al., 2015; Corrales et al., 2018) and at global scale
(Cheung et al., 2010, 2011; Blanchard et al., 2012; Carozza et al., 2018; Lotze et al., 2018; Bryndum-Buchholz et al., 2019) but not reporting at the same level of resolution in both species responses and spatial scales. In addition, the way species interactions are handled in OSMOSE, i.e., opportunistic and mechanistically formulated (vs. correlative or fixed trophic interactions), makes it appropriate to explore the impacts of future environmental changes, and allows to explore shifts in trophic structure.

The response of the Mediterranean Sea to climate change could have significant consequences for ecosystem productivity and biodiversity and hence for the overall goods and ecosystem services they provide, especially the production of living marine resources. Although our business-as-usual fishing scenario is simplistic (management and conservation plans will most likely be applied before the end of the century and fishing strategies will change), our catch projections showed contrasted patterns during the 21st century. By the middle of the century, most Geographical Sub-Areas (GSAs) exhibited a slight decline in catches as the loss of catch of native species was not compensated by gains in catch of thermophilic and/or exotic species. By the end of the century, the western and eastern part of the Mediterranean showed opposite trends with an increase of catch in all the eastern basin due to an increase in catch of thermophilic/exotic species and a decrease in catch in all the western basin due to the decrease of the biomass of several main exploited native species and the non-replacement by warm-water species. Our results suggest a tropicalization of catch composition in eastern GSAs of the Mediterranean Sea as already shown by Tsikliras and Stergiou (2014). In a context where one-third of the Mediterranean human population is concentrated along the coasts and is projected to grow, the question of the availability of food resources is crucial, especially in the southern countries where food demand is projected to increase most. With the proliferation of nonindigenous invasive species there is a need to explore market options for non-target species currently of low or no economic value (Weatherdon et al., 2016). Moreover, as shown by Lam et al. (2016), due to the increasing dominance of low value marine resources in the total world catches, an increase in catch does not necessarily translate into increases in revenues for fishing communities. The economic consequences of climate change on fisheries might manifest through changes in the price and value of catches (Sumaila et al., 2011). However, climate-induced changes may also offer new opportunities to some Mediterranean fisheries, with increased landings of warmwater species, some of which of high commercial interest (e.g., C. hippurus).

The projected increase in plankton production could provide opportunities to rebuild some overfished stocks, but climate change questions the relevance of current stock assessment models and management strategies to reach sustainable exploitation of all living marine resources. Several studies have indeed shown the potential synergistic effects of climate change and fishing on exploited populations and ecosystem functioning in the Mediterranean Sea and other regions of the world (e.g., Scheffer et al., 2001; Hsieh et al., 2006; Ottersen et al., 2006; 
Perry et al., 2010; Hidalgo et al., 2011; Quetglas et al., 2013; Tu et al., 2018). For instance, Hidalgo et al. (2011) showed that the erosion of the age structure of harvested hake populations in the Mediterranean Sea may drastically alter their capacity to dampen environmental fluctuations. Ignoring the effects of climate change in stock assessment could compromise the validity of stock forecasts and affect the robustness of several biological reference points such as the Maximum Sustainable Yield (MSY) (Brander, 2010; Grafton, 2010; Link et al., 2011; Galbraith et al., 2017; Serpetti et al., 2017). However, improved fisheries and ecosystems management in a highly overexploited Mediterranean Sea could have the potential to offset many negative effects of climate change (Roberts et al., 2017; Gaines et al., 2018).

\section{CONCLUSION}

This study projects climate change impacts on the biomass and fisheries catch at the whole Mediterranean scale under the high emission scenario RCP8.5. It is the first attempt to project future marine biodiversity over the whole Mediterranean Sea at fine resolution, and by explicitly considering climate-induced changes in plankton production, shifts in species distributions and their trophic interactions. Despite various uncertainties associated with projections, our results suggest that the high emission scenario RCP8.5 could result in an increase in total fish and macroinvertebrate biomass by 5 and $22 \%$, and in fisheries catch by 0.3 and $7 \%$ by $2021-2050$ and 2071-2100, respectively, overall mirroring changes in primary and secondary production in the Mediterranean Sea. These global increases masked several "losers" among modeled species while "winners" were mainly small pelagic species, thermophilic and/or exotic species, of smaller size and of low trophic levels. Projected increase in biomass and catch were expected in the southeastern part of the basin whereas significant decreases are most likely in the western Mediterranean Sea. We also showed that changes in the biogeography of species, associated with changes in productivity, could result in changes of Mediterranean ecosystem structure and trophic functioning by the end of the century. Combined with fishing pressure, climate change has the potential to render marine ecosystems more vulnerable to invasions by non-indigenous species. Finally, our results emphasized the importance of considering trophic interactions to improve predictions of biodiversity changes. The strong spatial contrasts in the projections also call for improved spatial management of marine resources across GSAs and collaboratively among states at the whole Mediterranean scale in order to mitigate global change effects in the region and create new opportunities for fisheries.

\section{REFERENCES}

Adloff, F., Somot, S., Sevault, F., Jordà, G., Aznar, R., Déqué, M., et al. (2015). Mediterranean Sea response to climate change in an ensemble of twenty first century scenarios. Clim. Dyn. 45, 2775-2802. doi: 10.1007/s00382-015-25072503

\section{DATA AVAILABILITY}

The raw data supporting the conclusions of this manuscript will be made available by the authors, without undue reservation, to any qualified researcher.

\section{AUTHOR CONTRIBUTIONS}

FM developed the model, acquired the data, and analyzed and interpreted the data. LV, NB, and Y-JS contributed to the data analysis and interpretation. FG and SD helped in the development of species distribution models. CU, PM, and SS provided the data on primary and secondary productions (from the biogeochemical model) and on climate environment (from the CNRM-RCSM4), respectively. NB helped with the programming code of OSMOSE and use of the HPC cluster DATARMOR. FM led the drafting of the manuscript with the contributions and revisions from all the authors.

\section{FUNDING}

FM was funded by a Ph.D. grant from the French Ministry of Higher Education, Research and Innovation. This work was partially funded by the USBIO project of the LabEx CeMEB, an ANR "Investissements d'avenir" program (ANR-10-LABX04-01) and the SOMBEE project of the joint BiodivERsA and Belmont Forum call “BiodivScen 2018” (ANR-18-EBI4-0003-01).

\section{ACKNOWLEDGMENTS}

The authors acknowledge the Pôle de Calcul et de Données Marines (PCDM) for providing DATARMOR computational resources (http://www.ifremer.fr/pcdm) and the CALMP computation center (Grant P1331) for the HPC resources, and the support of the SIROCCO team (http://sirocco.obs-mip. $\mathrm{fr} /$ ). The authors also acknowledge the CNRM for making the physical data available. The climatic simulations used in this work were downloaded from the Med-CORDEX database (www.medcordex.eu).

\section{SUPPLEMENTARY MATERIAL}

The Supplementary Material for this article can be found online at: https://www.frontiersin.org/articles/10.3389/fmars. 2019.00345/full\#supplementary-material

Ainsworth, C. H., Samhouri, J. F., Busch, D. S., Cheung, W. W., Dunne, J., and Okey, T. A. (2011). Potential impacts of climate change on Northeast Pacific marine foodwebs and fisheries. ICES J. Mar. Sci. 68, 1217-1229. doi: 10.1093/ icesjms/fsr043

Albouy, C., Guilhaumon, F., Araújo, M. B., Mouillot, D., and Leprieur, F. (2012). Combining projected changes in species richness and composition reveals 
climate change impacts on coastal Mediterranean fish assemblages. Glob. Change Biol. 18, 2995-3003. doi: 10.1111/j.1365-2486.2012.02772.x

Albouy, C., Guilhaumon, F., Leprieur, F., Lasram, F. B. R., Somot, S., Aznar, R., et al. (2013). Projected climate change and the changing biogeography of coastal Mediterranean fishes. J. Biogeogr. 40, 534-547. doi: 10.1111/jbi.12013

Albouy, C., Velez, L., Coll, M., Colloca, F., Loc'h, F. L., Mouillot, D., et al. (2014). From projected species distribution to food-web structure under climate change. Glob. Change Biol. 20, 730-741. doi: 10.1111/gcb.12467

Allan, B. J. M., Domenici, P., Watson, S. A., Munday, P. L., and McCormick, M. I. (2017). Warming has a greater effect than elevated $\mathrm{CO} 2$ on predator-prey interactions in coral reef fish. Proc. Biol. Sci. 284:20170784. doi: 10.1098/rspb. 2017.0784

Auger, P. A., Diaz, F., Ulses, C., Estournel, C., Neveux, J., Joux, F., et al. (2011). Functioning of the planktonic ecosystem on the Gulf of Lions shelf (NW Mediterranean) during spring and its impact on the carbon deposition: a field data and 3-D modelling combined approach. Biogeosciences 8, 32313261. doi: $10.5194 /$ bg-8-3231-2011

Azzurro, E., Moschella, P., and Maynou, F. (2011). Tracking signals of change in mediterranean fish diversity based on local ecological knowledge. PLoS One 6:e24885. doi: 10.1371/journal.pone.0024885

Barange, M., Merino, G., Blanchard, J. L., Scholtens, J., Harle, J., Allison, E. H., et al. (2014). Impacts of climate change on marine ecosystem production in societies dependent on fisheries. Nat. Clim. Change 4, 211-216. doi: 10.1038/ nclimate2119

Beaugrand, G., and Kirby, R. R. (2018). How do marine pelagic species respond to climate change? theories and observations. Annu. Rev. Mar. Sci. 10, 169-197. doi: 10.1146/annurev-marine-121916-163304

Ben Rais Lasram, F., Guilhaumon, F., Albouy, C., Somot, S., Thuiller, W., and Mouillot, D. (2010). The Mediterranean Sea as a 'cul-de-sac' for endemic fishes facing climate change. Glob. Change Biol. 16, 3233-3245. doi: 10.1111/j.13652486.2010.02224.x

Ben Rais Lasram, F., and Mouillot, D. (2008). Increasing southern invasion enhances congruence between endemic and exotic Mediterranean fish fauna. Biol. Invasions 11:697. doi: 10.1007/s10530-008-9284-9284

Benedetti, F., Ayata, S.-D., Irisson, J.-O., Adloff, F., and Guilhaumon, F. (2018). Climate change may have minor impact on zooplankton functional diversity in the Mediterranean Sea. Divers. Distrib. 25, 568-581. doi: 10.1111/ddi. 12857

Blanchard, J. L., Jennings, S., Holmes, R., Harle, J., Merino, G., Allen, J. I., et al. (2012). Potential consequences of climate change for primary production and fish production in large marine ecosystems. Philos. Trans. R. Soc. Lond. B. Biol. Sci. 367, 2979-2989. doi: 10.1098/rstb.2012.0231

Boero, F., Féral, J.-P., Azzurro, E., Cardin, V., Riedel, B., Despalatoviæ, M., et al. (2008). I-Executive summary of CIESM Workshop 35 'Climate warming and related changes in Mediterranean marine biota.' in CIESM workshop monographs. Available at: http://ciesm.org/online/monographs/35/WM_35_ 05_21.pdf [Accessed May 3, 2016]

Bopp, L., Aumont, O., Cadule, P., Alvain, S., and Gehlen, M. (2005). Response of diatoms distribution to global warming and potential implications: a global model study. Geophys. Res. Lett. 32. doi: 10.1029/2005GL 023653

Bopp, L., Resplandy, L., Orr, J. C., Doney, S. C., Dunne, J. P., Gehlen, M., et al. (2013). Multiple stressors of ocean ecosystems in the 21st century: projections with CMIP5 models. Biogeosciences 10, 6225-6245. doi: 10.5194/bg-10-62252013

Bourdaud, P., Gascuel, D., Bentorcha, A., and Brind'Amour, A. (2016). New trophic indicators and target values for an ecosystem-based management of fisheries. Ecol. Indic. 61, 588-601. doi: 10.1016/j.ecolind.2015.10.010

Boyd, P. W., Cornwall, C. E., Davison, A., Doney, S. C., Fourquez, M., Hurd, C. L., et al. (2016). Biological responses to environmental heterogeneity under future ocean conditions. Glob. Change Biol. 22, 2633-2650. doi: 10.1111/gcb. 13287

Brander, K. (2010). Impacts of climate change on fisheries. J. Mar. Syst. 79, 389-402. doi: 10.1016/j.jmarsys.2008.12.015

Brander, K. M. (2007). Global fish production and climate change. Proc. Natl. Acad. Sci. 104, 19709-19714. doi: 10.1073/pnas.0702059104

Brown, C. J., Fulton, E. A., Hobday, A. J., Matear, R. J., Possingham, H. P., Bulman, C., et al. (2010). Effects of climate-driven primary production change on marine food webs: implications for fisheries and conservation. Glob. Change Biol. 16, 1194-1212. doi: 10.1111/j.1365-2486.2009.02046.x

Bryndum-Buchholz, A., Tittensor, D. P., Blanchard, J. L., Cheung, W. W. L., Coll, M., Galbraith, E. D., et al. (2019). Twenty-first-century climate change impacts on marine animal biomass and ecosystem structure across ocean basins. Glob. Change Biol. 25, 459-472. doi: 10.1111/gcb.14512

Carozza, D. A., Bianchi, D., and Galbraith, E. D. (2018). Metabolic impacts of climate change on marine ecosystems: Implications for fish communities and fisheries. Glob. Ecol. Biogeogr. 28, 158-169. doi: 10.1111/geb. 12832

Cheung, W., Bruggeman, J., and Butenschön, M. (2018). "Projected changes in global and national potential marine fisheries catch under climate change scenarios in the twenty-first century," in Impacts of Climate Change on Fisheries and Aquaculture: Synthesis of Current Knowledge, Adaptation and Mitigation Options, eds M. Barange, T. Bahri, M. C. M. Beveridge, K. L. Cochrane, S. Funge-Smith, and F. Poulain (Rome: FAO).

Cheung, W. W. L. (2018). The future of fishes and fisheries in the changing oceans. J. Fish Biol. 92, 790-803. doi: 10.1111/jfb.13558

Cheung, W. W. L., Dunne, J., Sarmiento, J. L., and Pauly, D. (2011). Integrating ecophysiology and plankton dynamics into projected maximum fisheries catch potential under climate change in the Northeast Atlantic. ICES J. Mar. Sci. 68, 1008-1018. doi: 10.1093/icesjms/fsr012

Cheung, W. W. L., Jones, M. C., Reygondeau, G., Stock, C. A., Lam, V. W. Y., and Frölicher, T. L. (2016). Structural uncertainty in projecting global fisheries catches under climate change. Ecol. Model. 325, 57-66. doi: 10.1016/ j.ecolmodel.2015.12.018

Cheung, W. W. L., Lam, V. W. Y., Sarmiento, J. L., Kearney, K., Watson, R., Zeller, D., et al. (2010). Large-scale redistribution of maximum fisheries catch potential in the global ocean under climate change. Glob. Change Biol. 16, 24-35. doi: 10.1111/j.1365-2486.2009.01995.x

Cheung, W. W. L., Sarmiento, J. L., Dunne, J., Frölicher, T. L., Lam, V. W. Y., Palomares, M. L. D., et al. (2013). Shrinking of fishes exacerbates impacts of global ocean changes on marine ecosystems. Nat. Clim. Change 3, 254-258. doi: $10.1038 /$ nclimate 1691

Chevillot, X., Drouineau, H., Lambert, P., Carassou, L., Sautour, B., and Lobry, J. (2017). Toward a phenological mismatch in estuarine pelagic food web? PLoS One 12:e0173752. doi: 10.1371/journal.pone.0173752

Coll, M., Cury, P., Azzurro, E., Bariche, M., Bayadas, G., Bellido, J. M., et al. (2013). The scientific strategy needed to promote a regional ecosystem-based approach to fisheries in the Mediterranean and Black Seas. Rev. Fish Biol. Fish. 23, 415-434. doi: 10.1007/s11160-013-9305-y

Coll, M., and Libralato, S. (2012). Contributions of food web modelling to the ecosystem approach to marine resource management in the Mediterranean Sea. Fish Fish. 13, 60-88. doi: 10.1111/j.1467-2979.2011.00420.x

Coll, M., Piroddi, C., Albouy, C., Lasram, F. B. R., Cheung, W. W. L., Christensen, V., et al. (2012). The Mediterranean Sea under siege: spatial overlap between marine biodiversity, cumulative threats and marine reserves. Glob. Ecol. Biogeogr. 21, 465-480. doi: 10.1111/j.1466-8238.2011.00697.x

Coll, M., Piroddi, C., Steenbeek, J., Kaschner, K., Lasram, F. B. R., Aguzzi, J., et al. (2010). The Biodiversity of the Mediterranean Sea: estimates. patterns, and threats. PLoS One 5:e11842. doi: 10.1371/journal.pone.0011842

Colloca, F., Cardinale, M., Maynou, F., Giannoulaki, M., Scarcella, G., Jenko, K., et al. (2013). Rebuilding Mediterranean fisheries: a new paradigm for ecological sustainability. Fish Fish. 14, 89-109. doi: 10.1111/j.1467-2979.2011.00453.x

Colloca, F., Scarcella, G., and Libralato, S. (2017). Recent trends and impacts of fisheries exploitation on mediterranean stocks and ecosystems. Front. Mar. Sci. 4:244. doi: 10.3389/fmars.2017.00244

R Core Team (2018). R: A Language and Environment for Statistical Computing. R Foundation for Statistical Computing. https://www.R-project.org/

Corrales, X., Coll, M., Ofir, E., Heymans, J. J., Steenbeek, J., Goren, M., et al. (2018). Future scenarios of marine resources and ecosystem conditions in the Eastern Mediterranean under the impacts of fishing, alien species and sea warming. Sci. Rep. 8:14284. doi: 10.1038/s41598-018-32666-x

Crain, C. M., Kroeker, K., and Halpern, B. S. (2008). Interactive and cumulative effects of multiple human stressors in marine systems. Ecol. Lett. 11, 1304-1315. doi: 10.1111/j.1461-0248.2008.01253.x

Cramer, W., Guiot, J., Fader, M., Garrabou, J., Gattuso, J.-P., Iglesias, A., et al. (2018). Climate change and interconnected risks to sustainable development 
in the Mediterranean. Nat. Clim. Change 8, 972-980. doi: 10.1038/s41558-0180299-292

Crozier, L. G., and Hutchings, J. A. (2014). Plastic and evolutionary responses to climate change in fish. Evol. Appl. 7, 68-87. doi: 10.1111/eva.12135

Eppley, R. (1972). Temperature and phytoplankton growth in the sea. Fish. Bull. Nat. Ocean. Atmos. Adm. 70, 1063-1085.

FAO (2018). The State of World Fisheries and Aquaculture 2018 - Meeting the sustainable development goals. Rome: FAO.

Gaines, S. D., Costello, C., Owashi, B., Mangin, T., Bone, J., Molinos, J. G., et al. (2018). Improved fisheries management could offset many negative effects of climate change. Sci. Adv. 4:eaao1378. doi: 10.1126/sciadv.aao1378

Galbraith, E. D., Carozza, D. A., and Bianchi, D. (2017). A coupled humanEarth model perspective on long-term trends in the global marine fishery. Nat. Commun. 8:14884. doi: 10.1038/ncomms 14884

Galil, B. S. (2000). A sea under siege - alien species in the Mediterranean. Biol. Invasions 2, 177-186. doi: 10.1023/A:1010057010476

Garcia, H. E., Locarnini, R. A., Boyer, T. P., and Antonov, J. I. (2006). "World ocean atlas 2005," in Nutrients (Phosphate, Nitrate, and Silicate, ed. S. Levitus (Washington, D.C: U.S. Government Printing Office).

Garcia, S. M., Zerbi, A., Aliaume, C., Do Chi, T., and Lasserre, G. (2003). The Ecosystem Approach to FISHERIEs. Issues, Terminology, Principles, Institutional Foundations, Implementation and Outlook. Rome: FAO.

Giorgi, F. (2006). Climate change hot-spots. Geophys. Res. Lett. 33:L08707. doi: 10.1029/2006GL025734

Giorgi, F., and Lionello, P. (2008). Climate change projections for the Mediterranean region. Glob. Planet. Change 63, 90-104. doi: 10.1016/j.gloplacha. 2007.09.005

Grafton, R. Q. (2010). Adaptation to climate change in marine capture fisheries. Mar. Policy 34, 606-615. doi: 10.1016/j.marpol.2009.11.011

Grimm, V., Ayllón, D., and Railsback, S. F. (2017). Next-generation individualbased models integrate biodiversity and ecosystems: yes we can, and yes we must. Ecosystems 20, 229-236. doi: 10.1007/s10021-016-0071-72

Halpern, B. S., Frazier, M., Potapenko, J., Casey, K. S., Koenig, K., Longo, C., et al. (2015). Spatial and temporal changes in cumulative human impacts on the world's ocean. Nat. Commun. 6:7615. doi: 10.1038/ncomms8615

Hattab, T., Albouy, C., Lasram, F. B. R., Somot, S., Le Loc'h, F., and Leprieur, F. (2014). Towards a better understanding of potential impacts of climate change on marine species distribution: a multiscale modelling approach. Glob. Ecol. Biogeogr. 23, 1417-1429. doi: 10.1111/geb.12217

Hattab, T., Leprieur, F., Lasram, F. B. R., Gravel, D., Le Loc'h, F., and Albouy, C. (2016). Forecasting fine-scale changes in the food-web structure of coastal marine communities under climate change. Ecography 39, 1227-1237. doi: 10. 1111/ecog.01937

Henson, S. A., Beaulieu, C., Ilyina, T., John, J. G., Long, M., Séférian, R., et al. (2017). Rapid emergence of climate change in environmental drivers of marine ecosystems. Nat. Commun. 8:14682. doi: 10.1038/ncomms 14682

Herrmann, M., Estournel, C., Adloff, F., and Diaz, F. (2014). Impact of climate change on the northwestern Mediterranean Sea pelagic planktonic ecosystem and associated carbon cycle. J. Geophys. Res. Oceans 119, 5815-5836. doi: 10. 1002/2014JC010016

Hidalgo, M., Rouyer, T., Molinero, J., Massutí, E., Moranta, J., Guijarro, B., et al. (2011). Synergistic effects of fishing-induced demographic changes and climate variation on fish population dynamics. Mar. Ecol. Prog. Ser. 426, 1-12. doi: 10.3354/meps09077

Hiddink, J. G., Burrows, M. T., and García Molinos, J. (2015). Temperature tracking by North Sea benthic invertebrates in response to climate change. Glob. Change Biol. 21, 117-129. doi: 10.1111/gcb.12726

Hoegh-Guldberg, O., and Bruno, J. F. (2010). The impact of climate change on the world's marine ecosystems. Science 328, 1523-1528. doi: 10.1126/science. 1189930

Holt, J., Schrum, C., Cannaby, H., Daewel, U., Allen, I., Artioli, Y., et al. (2016). Potential impacts of climate change on the primary production of regional seas: A comparative analysis of five European seas. Prog. Oceanogr. 140, 91-115. doi: 10.1016/j.pocean.2015.11.004

Howes, E. L., Joos, F., Eakin, M., and Gattuso, J.-P. (2015). An updated synthesis of the observed and projected impacts of climate change on the chemical, physical and biological processes in the oceans. Front. Mar. Sci. 2:36. doi: 10.3389/fmars. 2015.00036

Hsieh, C., Reiss, C. S., Hunter, J. R., Beddington, J. R., May, R. M., and Sugihara, G. (2006). Fishing elevates variability in the abundance of exploited species. Nature 443, 859-862. doi: 10.1038/nature05232

IPCC (2014). "Climate Change 2014," in Synthesis Report. Contribution of Working Groups I, II and III to the Fifth Assessment Report of the Intergovernmental Panel on Climate Change, eds Core Writing Team, R. K. Pachauri and L. A. Meyer, Geneva: IPCC.

Jordà, G., Marbà, N., and Duarte, C. M. (2012). Mediterranean seagrass vulnerable to regional climate warming. Nat. Clim. Change 2, 821-824. doi: 10.1038/ nclimate 1533

Karl, D. M., Bidigare, R. R., and Letelier, R. M. (2001). Long-term changes in plankton community structure and productivity in the North Pacific Subtropical Gyre: The domain shift hypothesis. Deep Sea Res. Part II Top. Stud. Oceanogr. 48, 1449-1470. doi: 10.1016/S0967-0645(00)00 149-141

Kessouri, F. (2015). Cycles biogéochimiques de la mer Méditerranée: processus et bilans. PhD thesis, France: University Toulouse III Paul Sabatier

Lam, V. W. Y., Cheung, W. W. L., Reygondeau, G., and Sumaila, U. R. (2016). Projected change in global fisheries revenues under climate change. Sci. Rep. 6:32607. doi: 10.1038/srep32607

Lazzari, P., Mattia, G., Solidoro, C., Salon, S., Crise, A., Zavatarelli, M., et al. (2014). The impacts of climate change and environmental management policies on the trophic regimes in the Mediterranean Sea: scenario analyses. J. Mar. Syst. 135, 137-149. doi: 10.1016/j.jmarsys.2013.06.005

Lejeusne, C., Chevaldonné, P., Pergent-Martini, C., Boudouresque, C. F., and Pérez T. (2010). Climate change effects on a miniature ocean: the highly diverse, highly impacted Mediterranean Sea. Trends Ecol. Evol. 25, 250-260. doi: 10. 1016/j.tree.2009.10.009

Libralato, S., Caccin, A., and Pranovi, F. (2015). Modeling species invasions using thermal and trophic niche dynamics under climate change. Front. Mar. Sci. 2:29. doi: 10.3389/fmars.2015.00029

Link, J. S., Nye, J. A., and Hare, J. A. (2011). Guidelines for incorporating fish distribution shifts into a fisheries management context. Fish Fish. 12, 461-469. doi: 10.1111/j.1467-2979.2010.00398.x

Lotze, H. K., Tittensor, D. P., Bryndum-Buchholz, A., Eddy, T. D., Cheung, W. W., Galbraith, E. D., et al. (2018). Ensemble projections of global ocean animal biomass with climate change. bioRxiv doi: 10.1101/467175

Ludwig, W., Bouwman, A. F., Dumont, E., and Lespinas, F. (2010). Water and nutrient fluxes from major Mediterranean and Black Sea rivers: Past and future trends and their implications for the basin-scale budgets. Glob. Biogeochem. Cycles 24, GB0A13. doi: 10.1029/2009GB003594

Lynam, C. P., Llope, M., Möllmann, C., Helaouët, P., Bayliss-Brown, G. A., and Stenseth, N. C. (2017). Interaction between top-down and bottom-up control in marine food webs. Proc. Natl. Acad. Sci. U.S.A. 114, 1952-1957. doi: 10.1073/ pnas. 1621037114

Macias, D., Garcia-Gorriz, E., Piroddi, C., and Stips, A. (2014). Biogeochemical control of marine productivity in the Mediterranean Sea during the last 50 years. Glob. Biogeochem. Cycles 28, 897-907. doi: 10.1002/2014GB00 4846

Macias, D. M., Garcia-Gorriz, E., and Stips, A. (2015). Productivity changes in the Mediterranean Sea for the twenty-first century in response to changes in the regional atmospheric forcing. Front. Mar. Sci. 2:79. doi: 10.3389/fmars.2015. 00079

Manca, B., Burca, M., Giorgetti, A., Coatanoan, C., Garcia, M.-J., and Iona, A. (2004). Physical and biochemical averaged vertical profiles in the Mediterranean regions: an important tool to trace the climatology of water masses and to validate incoming data from operational oceanography. J. Mar. Syst. 48, 83-116. doi: 10.1016/j.jmarsys.2003.11.025

Mannino, A. M., Balistreri, P., and Deidun, A. (2017). “The Marine Biodiversity of the Mediterranean Sea in a Changing Climate," in The Impact of Biological Invasions. Mediterranean Identities - Environment, Society, Culture, ed. B. Fuerst-Bjelis, London: IntechOpen.

Marbà, N., and Duarte, C. M. (2010). Mediterranean warming triggers seagrass (Posidonia oceanica) shoot mortality. Glob. Change Biol. 16, 2366-2375. doi: 10.1111/j.1365-2486.2009.02130.x 
Marbà, N., Jorda, G., Agusti, S., Girard, C., and Duarte, C. M. (2015). Footprints of climate change on Mediterranean Sea biota. Front. Mar. Sci. 2:56. doi: 10.3389/ fmars.2015.00056

Mazumder, S. K., De, M., Mazlan, A. G., Zaidi, C. C., Rahim, S. M., and Simon, K. D. (2015). Impact of global climate change on fish growth, digestion and physiological status: developing a hypothesis for cause and effect relationships. J. Water Clim. Change 6, 200-226. doi: 10.2166/wcc.2014.146

Merino, G., Barange, M., Blanchard, J. L., Harle, J., Holmes, R., Allen, I., et al. (2012). Can marine fisheries and aquaculture meet fish demand from a growing human population in a changing climate? Glob. Environ. Change 22, 795-806. doi: 10.1016/j.gloenvcha.2012.03.003

Micheli, F., Halpern, B. S., Walbridge, S., Ciriaco, S., Ferretti, F., Fraschetti, S., et al. (2013). Cumulative human impacts on mediterranean and black sea marine ecosystems: assessing current pressures and opportunities. PLoS One 8:e79889. doi: 10.1371/journal.pone.0079889

Miller, D. D., Ota, Y., Sumaila, U. R., Cisneros-Montemayor, A. M., and Cheung, W. W. L. ( (2018). Adaptation strategies to climate change in marine systems. Glob. Change Biol. 24, e1-e14. doi: 10.1111/gcb.13829

Modica, L., Velasco, F., Preciado, I., Soto, M., and Greenstreet, S. P. R. (2014). Development of the large fish indicator and associated target for a Northeast Atlantic fish community. ICES J. Mar. Sci. 71, 2403-2415. doi: 10.1093/icesjms/ fsu101

Morán, X. A. G., López-Urrutia, Á., Calvo-Díaz, A., and Li, W. K. W. (2010). Increasing importance of small phytoplankton in a warmer ocean. Glob. Change Biol. 16, 1137-1144. doi: 10.1111/j.1365-2486.2009.01960.x

Moullec, F., Velez, L., Verley, P., Barrier, N., Ulses, C., Carbonara, P., et al. (2019). Catching the big picture of the Mediterranean Sea biodiversity with an end-to-end model of climate and fishing impacts. bioRxiv doi: 10.1101/59 3822

Nabat, P., Somot, S., Mallet, M., Michou, M., Sevault, F., Driouech, F., et al. (2015). Dust aerosol radiative effects during summer 2012 simulated with a coupled regional aerosol-atmosphere-ocean model over the Mediterranean. Atmospheric Chem. Phys. 15, 3303-3326. doi: 10.5194/acp-15-3303-2015

Nicholson, E., Fulton, E. A., Brooks, T. M., Blanchard, R., Leadley, P., Metzger, J. P., et al. (2018). Scenarios and models to support global conservation targets. Trends Ecol. Evol. 34, 57-68. doi: 10.1016/j.tree.2018.10.006

Ottersen, G., Hjermann, D. Ø, and Stenseth, N. C. (2006). Changes in spawning stock structure strengthen the link between climate and recruitment in a heavily fished cod (Gadus morhua) stock. Fish. Oceanogr. 15, 230-243. doi: 10.1111/j. 1365-2419.2006.00404.x

Parmesan, C., and Yohe, G. (2003). A globally coherent fingerprint of climate change impacts across natural systems. Nature 421, 37-42. doi: 10.1038/ nature 01286

Parravicini, V., Azzurro, E., Kulbicki, M., and Belmaker, J. (2015). Niche shift can impair the ability to predict invasion risk in the marine realm: an illustration using Mediterranean fish invaders. Ecol. Lett. 18, 246-253. doi: 10.1111/ele. 12401

Pauly, D. (2010). "Gasping Fish and Panting Squids," in Oxygen, Temperature and the Growth of Water Breathing Animals, 1st Edn, ed. O. Kinne (Germany: Ecology Institute).

Pauly, D., Christensen, V., Dalsgaard, J., Froese, R., and Torres, F. (1998). Fishing down marine food webs. Science 279, 860-863. doi: 10.1126/science.279. 5352.860

Peck, M. A., Arvanitidis, C., Butenschön, M., Canu, D. M., Chatzinikolaou, E., Cucco, A., et al. (2018). Projecting changes in the distribution and productivity of living marine resources: a critical review of the suite of modelling approaches used in the large European project VECTORS. Estuar. Coast. Shelf Sci. 201, 40-55. doi: 10.1016/j.ecss.2016.05.019

Pecl, G. T., Araújo, M. B., Bell, J. D., Blanchard, J., Bonebrake, T. C., Chen, I.C., et al. (2017). Biodiversity redistribution under climate change: Impacts on ecosystems and human well-being. Science 355:eaai9214. doi: 10.1126/science. aai9214

Perry, A. L., Low, P. J., Ellis, J. R., and Reynolds, J. D. (2005). Climate change and distribution shifts in marine fishes. Science 308, 1912-1915. doi: 10.1126/ science. 1111322

Perry, R. I., Cury, P., Brander, K., Jennings, S., Möllmann, C., and Planque, B. (2010). Sensitivity of marine systems to climate and fishing: Concepts, issues and management responses. J. Mar. Syst. 79, 427-435. doi: 10.1016/j.jmarsys. 2008.12.017

Pikitch, E. K., Santora, C., Babcock, E. A., Bakun, A., Bonfil, R., Conover, D. O., et al. (2004). Ecosystem-based fishery management. Science 305, 346-347. doi: $10.1126 /$ science. 1098222

Poloczanska, E. S., Burrows, M. T., Brown, C. J., García Molinos, J., Halpern, B. S., Hoegh-Guldberg, O., et al. (2016). Responses of marine organisms to climate change across oceans. Front. Mar. Sci. 3:62. doi: 10.3389/fmars.2016.00062

Pörtner, H.-O. (2010). Oxygen- and capacity-limitation of thermal tolerance: a matrix for integrating climate-related stressor effects in marine ecosystems. J. Exp. Biol. 213, 881-893. doi: 10.1242/jeb.037523

Pörtner, H. O., and Peck, M. A. (2010). Climate change effects on fishes and fisheries: towards a cause-and-effect understanding. J. Fish Biol. 77, 1745-1779. doi: 10.1111/j.1095-8649.2010.02783.x

Powley, H. R., Krom, M. D., and Cappellen, P. V. (2017). Understanding the unique biogeochemistry of the Mediterranean Sea: insights from a coupled phosphorus and nitrogen model. Glob. Biogeochem. Cycles 31, 1010-1031. doi: 10.1002/2017GB005648

Quetglas, A., Ordines, F., Hidalgo, M., Monserrat, S., Ruiz, S., Amores, Á, et al. (2013). Synchronous combined effects of fishing and climate within a demersal community. ICES J. Mar. Sci. 70, 319-328. doi: 10.1093/icesjms/fss181

R Core team (2015). R: A language and environment for statistical computing. R Foundation for Statistical Computing. URL https://www.R-project.org/.

Ramírez, F., Coll, M., Navarro, J., Bustamante, J., and Green, A. J. (2018). Spatial congruence between multiple stressors in the Mediterranean Sea may reduce its resilience to climate impacts. Sci. Rep. 8:14871. doi: 10.1038/s41598-01833237-w

Riahi, K., Rao, S., Krey, V., Cho, C., Chirkov, V., Fischer, G., et al. (2011). RCP 8.5-A scenario of comparatively high greenhouse gas emissions. Clim. Change 109:33. doi: 10.1007/s10584-011-0149-y

Ribera d'Alcalà, M. (2003). Nutrient ratios and fluxes hint at overlooked processes in the Mediterranean Sea. J. Geophys. Res. 108:8106. doi: 10.1029/ 2002JC001650

Richon, C., Dutay, J.-C., Bopp, L., Vu, B. L., Orr, J. C., Somot, S., et al. (2019). Biogeochemical response of the Mediterranean Sea to the transient SRES-A2 climate change scenario. Biogeosciences 16, 135-165. doi: 10.5194/bg-16-1352019

Richon, C., Dutay, J.-C., Dulac, F., Wang, R., Balkanski, Y., Nabat, P., et al. (2018). Modeling the impacts of atmospheric deposition of nitrogen and desert dustderived phosphorus on nutrients and biological budgets of the Mediterranean Sea. Prog. Oceanogr. 163, 21-39. doi: 10.1016/j.pocean.2017.04.009

Roberts, C. M., O’Leary, B. C., McCauley, D. J., Cury, P. M., Duarte, C. M., Lubchenco, J., et al. (2017). Marine reserves can mitigate and promote adaptation to climate change. Proc. Natl. Acad. Sci. U.S.A. 114, 6167-6175. doi: $10.1073 /$ pnas. 1701262114

Rogelj, J., Meinshausen, M., and Knutti, R. (2012). Global warming under old and new scenarios using IPCC climate sensitivity range estimates. Nat. Clim. Change 2, 248-253. doi: 10.1038/nclimate1385

Sarmiento, J. L., Hughes, T. M. C., Stouffer, R. J., and Manabe, S. (1998). Simulated response of the ocean carbon cycle to anthropogenic climate warming. Nature 393:245. doi: $10.1038 / 30455$

Scheffer, M., Carpenter, S., Foley, J. A., Folke, C., and Walker, B. (2001). Catastrophic shifts in ecosystems. Nature 413, 591-596. doi: 10.1038/3509 8000

Schweiger, O., Settele, J., Kudrna, O., Klotz, S., and Kühn, I. (2008). Climate change can cause spatial mismatch of trophically interacting species. Ecology 89, 3472-3479. doi: 10.1890/07-1748.1

Seidl, R. (2017). To model or not to model. that is no longer the question for ecologists. Ecosystems 20, 222-228. doi: 10.1007/s10021-016-0068-X

Selden, R. L., Batt, R. D., Saba, V. S., and Pinsky, M. L. (2018). Diversity in thermal affinity among key piscivores buffers impacts of ocean warming on predator-prey interactions. Glob. Change Biol. 24, 117-131. doi: 10.1111/gcb. 13838

Serpetti, N., Baudron, A. R., Burrows, M. T., Payne, B. L., Helaouët, P., Fernandes, P. G., et al. (2017). Impact of ocean warming on sustainable fisheries management informs the Ecosystem Approach to Fisheries. Sci. Rep. 7:13438. doi: 10.1038/s41598-017-13220-13227 
Sevault, F., Somot, S., Alias, A., Dubois, C., Lebeaupin-Brossier, C., Nabat, P., et al. (2014). A fully coupled Mediterranean regional climate system model: design and evaluation of the ocean component for the 1980-2012 period. Tellus Dyn. Meteorol. Oceanogr. 66:23967. doi: 10.3402/tellusa.v66.23967

Shin, Y.-J., and Cury, P. (2001). Exploring fish community dynamics through size-dependent trophic interactions using a spatialized individual-based model. Aquat. Living Resour. 14, 65-80. doi: 10.1016/S0990-7440(01)011061108

Shin, Y.-J., and Cury, P. (2004). Using an individual-based model of fish assemblages to study the response of size spectra to changes in fishing. Can. J. Fish. Aquat. Sci. 61, 414-431. doi: 10.1139/f03-154

Somot, S., Sevault, F., and Déqué, M. (2006). Transient climate change scenario simulation of the Mediterranean Sea for the twenty-first century using a highresolution ocean circulation model. Clim. Dyn. 27, 851-879. doi: 10.1007/ s00382-006-0167-z

Steinacher, M., Joos, F., Frölicher, T. L., Bopp, L., Cadule, P., Cocco, V., et al. (2010). Projected 21st century decrease in marine productivity: a multi-model analysis. Biogeosciences 7, 979-1005. doi: 10.5194/bg-7-979-2010

Sumaila, U. R., Cheung, W. W. L., Lam, V. W. Y., Pauly, D., and Herrick, S. (2011). Climate change impacts on the biophysics and economics of world fisheries. Nat. Clim. Change 1, 449-456. doi: 10.1038/nclimate1301

Taucher, J., and Oschlies, A. (2011). Can we predict the direction of marine primary production change under global warming? Geophys. Res. Lett. 38:L02603. doi: 10.1029/2010GL045934

Thuiller, W., Lafourcade, B., Engler, R., and Araújo, M. B. (2009). BIOMOD a platform for ensemble forecasting of species distributions. Ecography 32, 369-373. doi: 10.1111/j.1600-0587.2008.05742.x

Travers, M., Shin, Y.-J., Jennings, S., Machu, E., Huggett, J. A., Field, J. G., et al. (2009). Two-way coupling versus one-way forcing of plankton and fish models to predict ecosystem changes in the Benguela. Ecol. Model. 220, 3089-3099. doi: 10.1016/j.ecolmodel.2009.08.016

Travers-Trolet, M., Shin, Y.-J., and Field, J. G. (2014a). An end-to-end coupled model ROMS-N2P2Z2D2-OSMOSE of the southern Benguela foodweb: parameterisation, calibration and pattern-oriented validation. Afr. J. Mar. Sci. 36, 11-29. doi: 10.2989/1814232X.2014.883326

Travers-Trolet, M., Shin, Y.-J., Shannon, L. J., Moloney, C. L., and Field, J. G. (2014b). Combined fishing and climate forcing in the southern benguela upwelling ecosystem: an end-to-end modelling approach reveals dampened effects. PLoS One 9:e94286. doi: 10.1371/journal.pone.0094286

Tsikliras, A. C., and Stergiou, K. I. (2014). Mean temperature of the catch increases quickly in the Mediterranean Sea. Mar. Ecol. Prog. Ser. 515, 281-284. doi: 10.3354/meps11005

Tu, C.-Y., Chen, K.-T., and Hsieh, C. (2018). Fishing and temperature effects on the size structure of exploited fish stocks. Sci. Rep. 8:7132. doi: 10.1038/s41598018-25403-x

Tzanatos, E., Raitsos, D. E., Triantafyllou, G., Somarakis, S., and Tsonis, A. A. (2014). Indications of a climate effect on Mediterranean fisheries. Clim. Change 122, 41-54. doi: 10.1007/s10584-013-0972-974

Ulses, C., Auger, P.-A., Soetaert, K., Marsaleix, P., Diaz, F., Coppola, L., et al. (2016). Budget of organic carbon in the North-Western Mediterranean open sea over the period 2004-2008 using 3-D coupled physical-biogeochemical modeling. J. Geophys. Res. Oceans 121, 7026-7055. doi: 10.1002/2016JC011818

Urban, M. C., Bocedi, G., Hendry, A. P., Mihoub, J.-B., Pe'er, G., Singer, A., et al. (2016). Improving the forecast for biodiversity under climate change. Science 353:aad8466. doi: 10.1126/science.aad8466

Voldoire, A., Sanchez-Gomez, E., Salas y Mélia, D., Decharme, B., Cassou, C., Sénési, S., et al. (2013). The CNRM-CM5.1 global climate model: description and basic evaluation. Clim. Dyn. 40, 2091-2121. doi: 10.1007/s00382-011-1259-y

Weatherdon, L. V., Magnan, A. K., Rogers, A. D., Sumaila, U. R., and Cheung, W. W. L. (2016). Observed and projected impacts of climate change on marine fisheries, aquaculture, coastal tourism, and human health: an update. Front. Mar. Sci. 3:48. doi: 10.3389/fmars.2016.00048

Conflict of Interest Statement: The authors declare that the research was conducted in the absence of any commercial or financial relationships that could be construed as a potential conflict of interest.

Copyright (c) 2019 Moullec, Barrier, Drira, Guilhaumon, Marsaleix, Somot, Ulses, Velez and Shin. This is an open-access article distributed under the terms of the Creative Commons Attribution License (CC BY). The use, distribution or reproduction in other forums is permitted, provided the original author(s) and the copyright owner(s) are credited and that the original publication in this journal is cited, in accordance with accepted academic practice. No use, distribution or reproduction is permitted which does not comply with these terms. 